\title{
Reducing Energy Use in Existing Homes by $30 \%$ : Learning From Home Performance with ENERGY STAR
}

Christine Liaukus Building America Research Alliance

December 2014 


\section{NOTICE}

This report was prepared as an account of work sponsored by an agency of the United States government. Neither the United States government nor any agency thereof, nor any of their employees, subcontractors, or affiliated partners makes any warranty, express or implied, or assumes any legal liability or responsibility for the accuracy, completeness, or usefulness of any information, apparatus, product, or process disclosed, or represents that its use would not infringe privately owned rights. Reference herein to any specific commercial product, process, or service by trade name, trademark, manufacturer, or otherwise does not necessarily constitute or imply its endorsement, recommendation, or favoring by the United States government or any agency thereof. The views and opinions of authors expressed herein do not necessarily state or reflect those of the United States government or any agency thereof.

Available electronically at http://www.osti.gov/bridge

Available for a processing fee to U.S. Department of Energy

and its contractors, in paper, from:

U.S. Department of Energy

Office of Scientific and Technical Information

P.O. Box 62

Oak Ridge, TN 37831-0062

phone: 865.576.8401

fax: 865.576.5728

email: mailto:reports@adonis.osti.gov

Available for sale to the public, in paper, from:

U.S. Department of Commerce

National Technical Information Service

5285 Port Royal Road

Springfield, VA 22161

phone: 800.553 .6847

fax: 703.605 .6900

email: orders@ntis.fedworld.gov

online ordering: http://www.ntis.gov/ordering.htm

Printed on paper containing at least $50 \%$ wastepaper, including $20 \%$ postconsumer waste 


\title{
Reducing Energy Use in Existing Homes by 30\%: Learning From Home Performance with ENERGY STAR
}

\author{
Prepared for:
}

The National Renewable Energy Laboratory

On behalf of the U.S. Department of Energy's Building America Program

Office of Energy Efficiency and Renewable Energy

15013 Denver West Parkway

Golden, CO 80401

NREL Contract No. DE-AC36-08GO28308

Prepared by:

Christine Liaukus

Building America Research Alliance (BARA)

12932 SE Kent-Kangley Road, Suite 529

Kent, WA 98030

NREL Technical Monitor: Cheryn Metzger

Prepared under Subcontract No. KNDJ-0-40336-04

December 2014 
[This page left blank] 


\section{Contents}

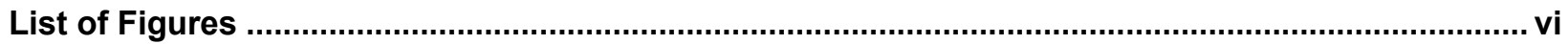

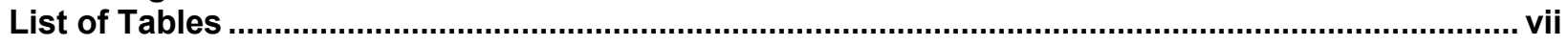

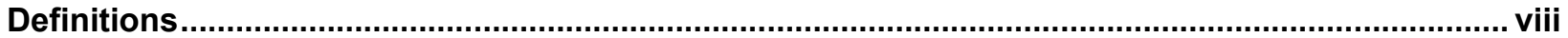

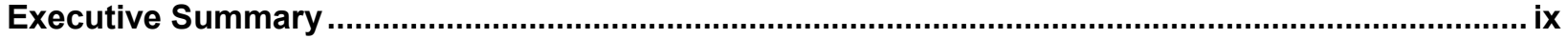

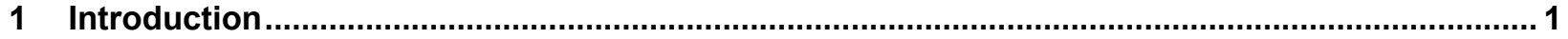

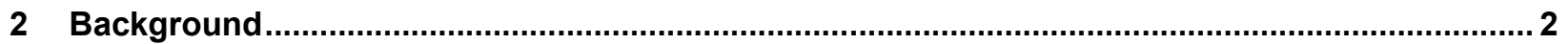

2.1 Home Performance with ENERGY STAR ….........................................................

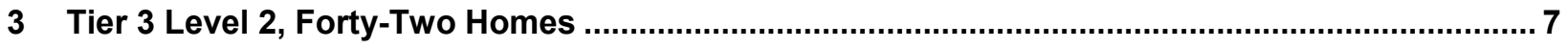

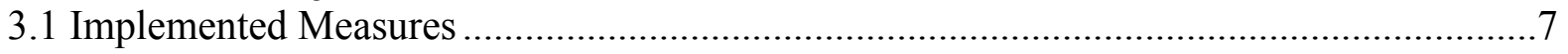

3.1.1 Air Sealing -Forty-Two Homes...........................................................

3.1.2 Heating System Replacement-Thirty-Nine Homes......................................... 10

3.1.3 Attic Access Insulation - Thirty-Two Homes .................................................... 11

3.1.4 Installation of Central Air Conditioning - 31 Homes.........................................11

3.1.5 Floor/Ceiling Insulation - Thirty-One Homes............................................. 12

3.1.6 Water Heater Replacement - Thirty Homes ............................................... 13

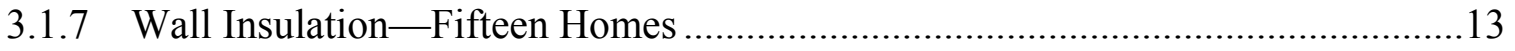

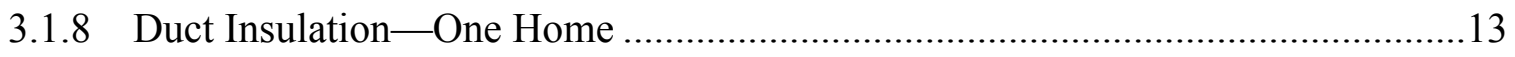

3.2 Implemented Packages of Measures ...........................................................................13

4 Tier 3 Level 2 Homes With Utility Data-Seventeen Homes ................................................... 15

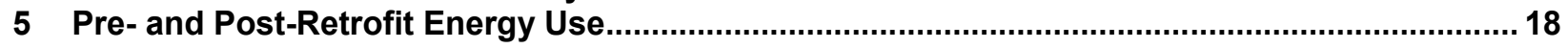

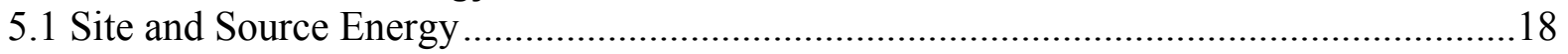

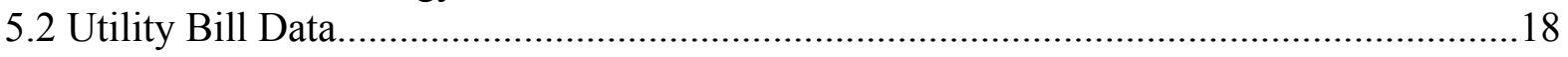

5.3 Weather Normalization of Utility Data............................................................. 21

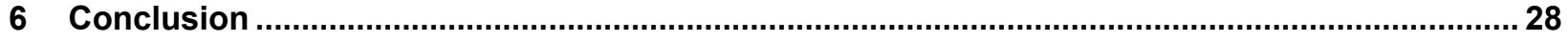

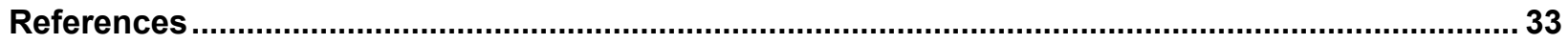

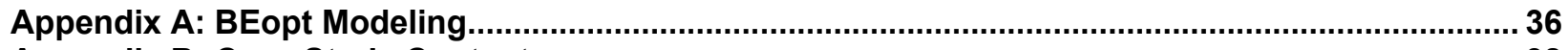

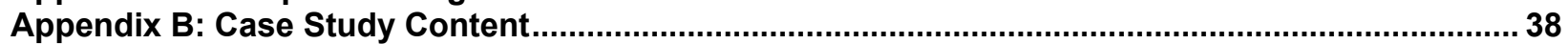




\section{List of Figures}

Figure 1. U.S. climate zone map (U.S. DOE, 2013)

Figure 2. New Jersey counties and climate zones (Liaukus C. , 2014) ...............................................

Figure 3. Existing CFM50 among 42 tier 3 level 2 homes .............................................................. 8

Figure 4. Existing ACH50 among 42 tier 3 level 2 homes ........................................................... 8

Figure 5. Post-air sealing CFM50 among 42 tier 3 level 2 homes .................................................... 9

Figure 6. Post air sealing ACH50 among 42 tier 3 level 2 homes .................................................... 9

Figure 7. Blower door result guidelines (Krigger \& Dorsi, 2009) ..................................................... 10

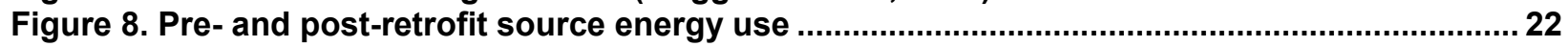

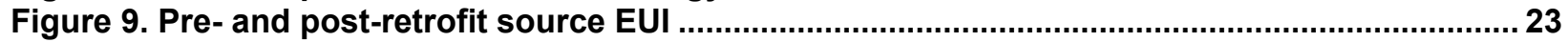

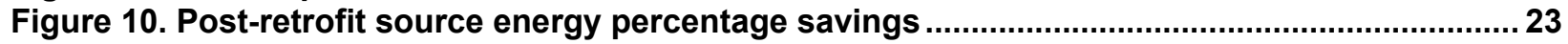

Figure 11. Pre-retrofit source energy use and percentage savings ................................................ 24

Figure 12. Conditioned floor area and post-retrofit source EUI........................................................25

Figure 13. Retrofit cost and percentage source energy savings .................................................... 25

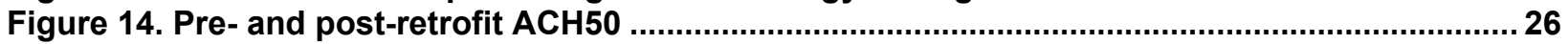

Figure 15. Estimated and actual savings for 17 Tier 3 Level 2 homes ............................................ 27

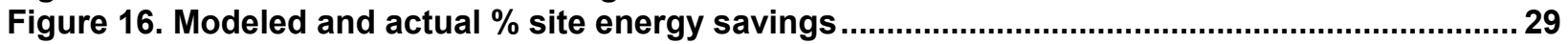

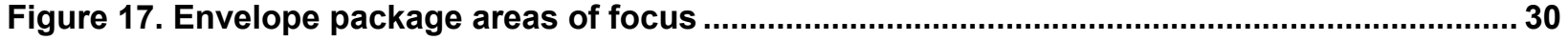

Figure 18. Existing conditions suited to envelope package and mechanicals package .................. 31

Figure 19. House ACH as a function of age (Cummings, Tooley, \& Moyer, 1991) ............................ 32

Figure 20. Envelope package areas of focus .......................................................................... 40

Figure 21. Existing conditions suited to envelope package and mechanicals package ...................41

Figure 22. Infiltration percentage reduction .................................................................................... 42

Unless otherwise noted, all figures were created by BARA. 


\section{List of Tables}

Table 1. New Jersey HPwES Requirements and Incentives ....................................................... 4

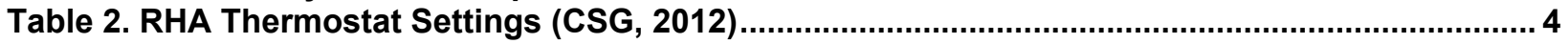

Table 3. Summarized New Jersey HPwES Eligible Measures List (NJ Office of Clean Energy, 2012)5

Table 4. Energy Conservation Measures Implemented in 42 Tier 3 Level 2 New Jersey HPwES Homes

Table 5. Existing Heating Systems Among 39 Homes With Heating System Replacement ................ 11

Table 6. Replacement Heating Systems Among 39 Homes With Heating System Replacement ..... 11

Table 7. Existing Central AC Systems Among 31 Homes With Central AC Installation....................11

Table 8. New Central AC System Efficiency Among 31 Homes With Central AC Installation .......... 12

Table 9. Added Attic Floor Insulation Among 31 Homes.............................................................. 12

Table 10. Replacement Water Heaters Among 30 Homes .......................................................... 13

Table 11. Wall Insulation Installed in 15 Homes .......................................................................... 13

Table 12. Sixteen Package Combinations Among 42 Homes.......................................................... 14

Table 13. Installed Energy Conservation Measures in Tier 3 Level 2 Homes with Utility Data......... 16

Table 14. Source-Site Ratios for Commonly Used Fuels (US EPA, 2011) ........................................ 18

Table 15. Utility Bill Data and Time Periods for the 17 Houses..................................................... 19

Table 16. Comparison of Modeled Site and Actual Percentage Savings ......................................29

Table 17. Proposed Prescriptive Packages To Achieve 30\% Savings in Climate Zones 4 and $5 \ldots . . .31$

Table 18. BEopt Model House Delran: Existing Conditions, HPwES Package, BARA Envelope Package, and BARA Envelope + HVAC Package ................................................................. 36

Table 19. BEopt Model of House Mahwah: Existing Conditions, HPwES Package, BARA Envelope Package, and BARA Envelope + HVAC Package ....................................................................... 37

Table 20. Proposed Prescriptive Packages To Achieve 30\% Savings in Climate Zones 4 and $5 \ldots . . .39$

Unless otherwise noted, all tables were created by BARA. 


\section{Definitions}

$\mathrm{AC}$

$\mathrm{ACH}$

ACH50

AFUE

BA

BARA

BAS

BPI

Btu

CDD

COP

CSG

CFM50

DHW

EER

EF

EUI

HDD

HSFP

HVAC

$\mathrm{kWh}$

MMBtu

RHA

SEER

TES
Air Conditioner

Air Changes per Hour

Air Changes per Hour at 50 Pascals

Annual Fuel Utilization Efficiency

Building America

Building America Research Alliance

Building Airflow Standard

Building Performance Institute

British thermal unit

Cooling Degree Day

Coefficient of Performance

Conservation Services Group

Cubic Feet per Minute at 50 Pascals

Domestic Hot Water

Energy Efficiency Ratio

Energy Factor

Energy Use Intensity

Heating Degree Day

Heating Season Performance Factor

Heating, Ventilation, and Air Conditioning

Kilowatt-hour

Million British thermal units

Real Home Analyzer

Seasonal Energy Efficiency Ratio

Total (Site) Energy Savings 


\section{Executive Summary}

The improvement of existing homes in the United States can have a much greater impact on overall residential energy use than the construction of highly efficient new homes. There are more than 130 million existing housing units in the United States, while annually new construction represents less than $2 \%$ of the total supply (U.S. Census Bureau, 2013). Therefore, the existing housing stock presents a clear opportunity and responsibility for Building America (BA) to guide the remodeling and retrofit market toward higher performance existing homes.

There are active programs designed to improve the energy performance of existing homes. Home Performance with ENERGY STAR ${ }^{\circledR}$ (HPwES) is the largest non-income-qualified (market rate) program, active in 35 states (VonSchrader, 2014). Drawing best practices from programs such as HPwES and augmenting their efforts is a logical strategy to pinpoint and better implement the most cost-effective energy efficiency measures (other than those targeting occupant behavior) to reduce energy use in homes nationwide.

The Building America Research Alliance's research in this project was to verify whether homes in the New Jersey HPwES program achieved 30\% source energy savings, and if so, what measures were implemented to achieve them. ${ }^{1}$ While site energy savings ranging from $10 \%$ to $25 \%$ or greater are estimated for the different HPwES tiers, no research has been done in the New Jersey program to verify actual savings by comparing pre- and post-retrofit utility bill data, and documenting the measures implemented to achieve those savings. Of the $17^{2} \mathrm{HPwES}$ projects with utility data included in this report, 16 have source energy savings ranging from $27 \%$ to $61 \%$. Further, two of the homes achieved that level of source energy savings without the costly replacement of heating and cooling equipment, which indicates that less costly envelope packages could be offered to consumers who are unable to invest in more costly mechanical packages, potentially creating broader market impact. The energy retrofit costs of the 13 homes that included heating, ventilation, and air conditioning (HVAC) measures averaged \$13,622 and their average source energy savings was $41 \%$. The energy retrofit costs of the two homes without HVAC measures averaged $\$ 9,313$ and their average source energy savings was $29 \%$. The vast majority of homes in the program did have heating and/or cooling equipment replaced, but that may be more a result of the expertise of the contractors participating in the program rather than the necessity of equipment replacement for significant energy savings.

The packages of measures used in the New Jersey HPwES program, both those with and without HVAC equipment replacement, can be included as part of the BA retrofit checklist for climate zones 4 and 5 (see Figures 1 and 2). Pairing the findings from this research with existing BA guidance documents, such as the Building America Best Practices Series, Energy Renovations, HVAC, (Pacific Northwest National Laboratory \& Oak Ridge National Laboratory, 2011) can help guide retrofit packages that tailor their approach toward more robust envelope improvements before mechanical equipment is replaced, resulting in relatively low-cost, high-impact energy improvement packages. Findings from this research, and subsequent research efforts,

\footnotetext{
${ }^{1}$ The $30 \%$ source energy savings is to be based on utility bill data or comparing modeled versus actual performance. Weather normalization of data is preferred (Metzger, 2014).

${ }^{2}$ Eighteen homes were initially included in the research. One home did not have electrical utility data from the preretrofit period.
} 
could serve to be the basis of BA "proven performance packages" for existing homes that could be implemented through the HPwES program, thus achieving programmatic goals of providing research and guidance for improving our nation's existing housing stock. Figure 1 shows the U.S. climate zones.

\section{International Energy Conservation Code (IECC) Climate Regions}

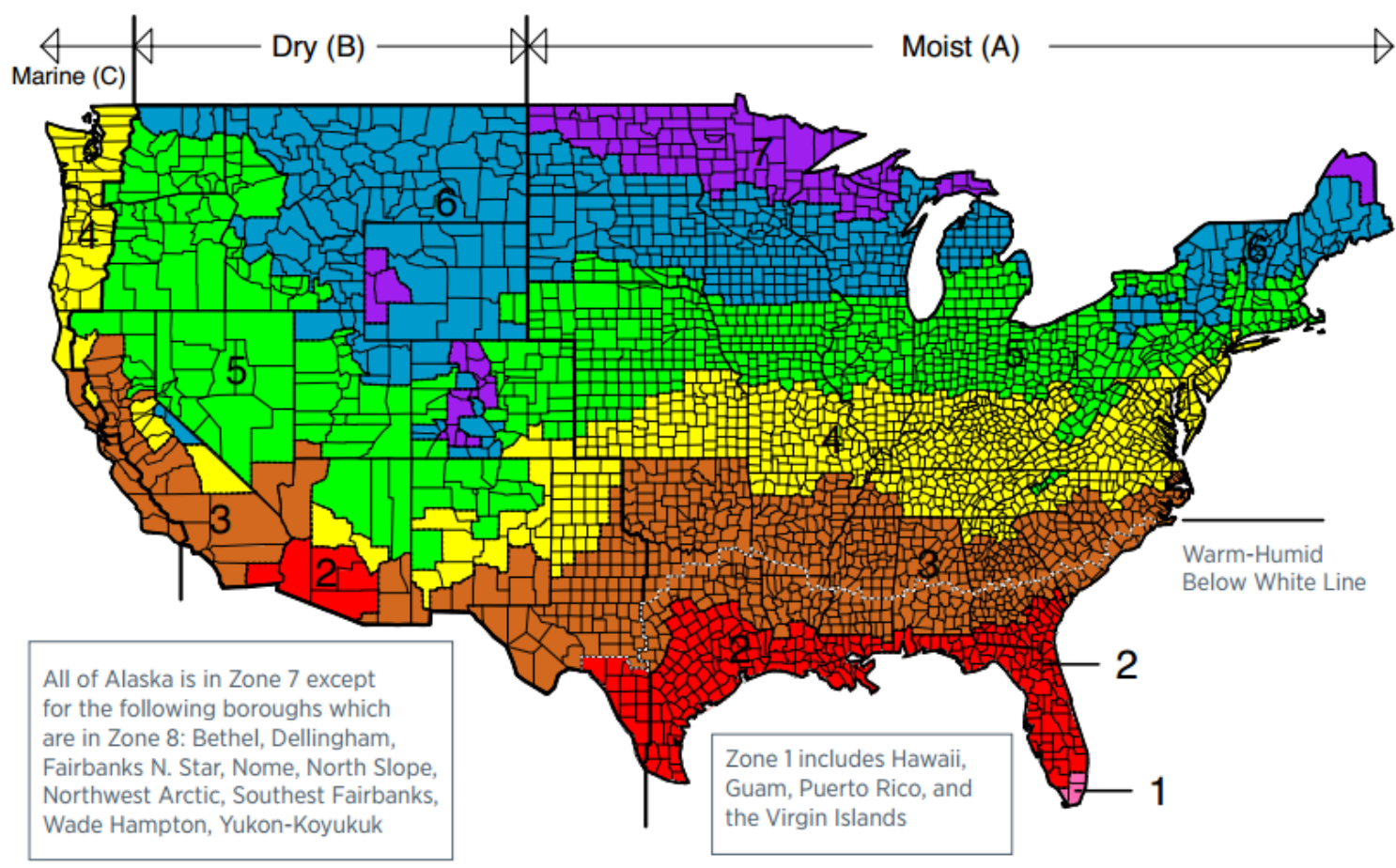

Figure 1. U.S. climate zone map (U.S. DOE, 2013)

New Jersey has a mixed-humid climate straddling climate zones 4 and 5. Eight northern counties are in climate zone 5, and 13 central and southern counties are in climate zone 4 (Figure 2).

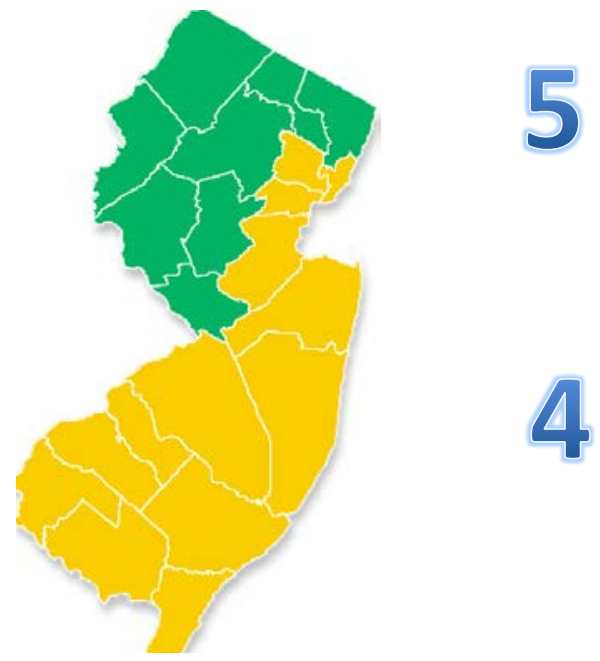

Figure 2. New Jersey counties and climate zones (Liaukus C. , 2014) 


\section{Introduction}

Building America (BA) has made significant strides in developing whole-house, proven performance packages to achieve high levels of energy savings - creating solid technical strategies for net-zero energy-ready homes - for new construction. However, whole-house, proven performance packages have been more difficult to develop for existing homes for a wide variety of reasons previously identified by researchers and practitioners (e.g., housing vintage, construction type). Data on actual savings achieved in homes with energy improvements are needed so that the most effective packages are developed and promoted by the BA program. Improving the energy efficiency of existing U.S. homes is critical for energy reduction in the residential sector. New construction accounts for a small fraction of the more than 130 million dwellings nationwide (U.S. Census Bureau, 2013).

Home Performance with ENERGY STAR ${ }^{\circledR}$ (HPwES) is the largest national energy retrofit initiative (VonSchrader, 2014) and has been the mechanism for improving more than 337,000 homes since 2002 (DOE, 2014). HPwES uses a "house as a system" approach and focuses on improvements to the building envelope and mechanical systems. HPwES contractors conduct energy audits on participating homes, prepare reports with recommended energy efficiency measures from an approved measures list, and install the selected measures. In New Jersey, those measures always include envelope air sealing (this is a required measure) and often include replacement of the heating system. While the efficiency of heating and cooling equipment continues to improve, pulled along by the mechanical code, technological improvements, and other factors, the building envelopes they are installed in often lag in performance. Because the building envelope can last 100 years or more, it is not uncommon for a minimally maintained decades-old building shell to be paired with new, highly efficient mechanical equipment. Data have shown that most existing homes could easily be tightened $25 \%$ and still not require mechanical ventilation for acceptable indoor air quality (Sherman, 2010). Beyond infiltration, homes built prior to 1980 often have inadequate wall insulation (Roberts \& Stephenson, 2010). Homes built before 1980 account for $67 \%$ of the U.S. housing stock (U.S. Census Bureau, 2011).

Possible obstacles to improving a home's building envelope to the same degree as the mechanical equipment are that envelope improvements can be difficult, intrusive, and not as profitable for the contractor as equipment replacement. Among the 42 homes at the top level of estimated site energy savings in the 2011 New Jersey HPwES program, 39 had their heating systems replaced and 31 had air conditioning (AC) installed or replaced. While only three homes did not have heating or cooling replaced, two of the three achieved significant source energy savings of $27 \%$ and $32 \%$. From the limited dataset examined for this research, it appears that there is the potential for further cost-effective envelope improvements before necessarily replacing mechanical equipment in many existing homes while still achieving source energy savings that meet the $30 \%$ BA goal. 


\section{Background}

New Jersey is one of 35 states with an active HPwES program. The New Jersey HPwES is part of New Jersey's Clean Energy Program, funded through the service benefits charge collected by the state's utilities and administered by the Board of Public Utilities. Nationally, the HPwES program has improved more than 337,000 homes since 2002 (DOE, 2014). The New Jersey program has improved 12,033 homes since it began in 2006. HPwES projects have estimated site energy savings of $10 \%-25 \%+$, depending on the implemented measures. These estimated savings are based on energy modeling with utility data input for pre-retrofit site energy use.

A 2007 National Renewable Energy Laboratory and Pacific Northwest National Laboratory study of Austin Electric's HPwES program found that in more than 6,000 homes in Austin, Texas, the measured savings were in the range of $25 \%-35 \%$, based on utility bill data (Belzer, 2007). These savings are in the range of BA goals. While this study did include utility data, it did not include a listing of the energy efficiency measures implemented to meet those savings.

In a 2012 BA study, "Proven Performance of Seven Cold Climate Deep Retrofit Homes" (Osser, 2012), three of the seven houses researched did not have adequate pre-retrofit utility bill data. As such, energy modeling was used to estimate energy use prior to the retrofit work. The report suggests that the Building America House Performance Database should include entry fields for monthly utility data. The Consortium for Advanced Residential Buildings team's "Retrofit NYC: Block by Block" report (Eisenberg, 2011) includes a limited number of units where utility bill analysis was completed. Originally, utility bill analysis was planned for all units, but the data were not available. Both reports discuss the importance of utility bill data both pre- and postretrofit for the evaluation of energy efficiency measure effectiveness.

In the 2011 Building America Research Alliance (BARA) team document "Best Practice: Commercially Viable Energy Efficiency Solution Package Report" (Liaukus, 2011), the BARA team modeled an existing home in New Jersey with a package of energy efficiency measures typically used in the New Jersey HPwES program. The vast majority of New Jersey HPwES program participants implemented a combination of envelope air sealing at the attic and basement or crawlspace; added insulation in the attic, and other insulation; and upgraded heating, cooling, and/or domestic hot water (DHW) equipment (Boyd, 2011). This combination of measures typically yields $25 \%$ or greater modeled site energy savings for homes in the program. With the increasing questioning of modeling predictions across many platforms, an investigation of measured savings was warranted. A study by the Energy Trust of Oregon found that the accuracy of four energy modeling software programs varied widely, but even the most accurate had a mean absolute percent error of $25.1 \%$, and the least accurate had a mean absolute percent error of $96.6 \%$ (Energy Trust of Oregon, 2009). As such, determining actual measured savings using utility bill data is highly desirable.

For this research, BARA worked with the New Jersey HPwES program, the New Jersey Clean Energy Program, and eight utilities in New Jersey to evaluate the packages of measures 
implemented in 17 homes that have achieved source energy savings in the range of $30 \%{ }^{3}$. These savings are based on utility bill data, not only modeled savings.

\subsection{Home Performance with ENERGY STAR}

HPwES is the only national market-rate federally supported, energy retrofit initiative. The program is well connected throughout the country to state and utility programs and can be used to deliver BA technical research results, such as the BA Best Practices Series, in actionable, measurable packages. The program has the infrastructure necessary to produce and deliver technical, information, and outreach tools to its participants that can create change in large markets. Not inconsequentally, the program has the ENERGY STAR brand behind it and has significant consumer and trade recognition that gives it valuable leverage.

The New Jersey Clean Energy Program is the sponsor of the New Jersey HPwES program. Among the 33 states with active HPwES programs, New Jersey is a high volume program, with more than 2,000 projects completed in 2013 (DOE, 2014). The New Jersey program has improved 12,033 homes since it began in 2006 (Lupse, 2013).

Contractors participating in New Jersey's HPwES program meet the certification and accreditation guidelines of the Building Performance Institute (BPI), an industry resource for building science technology that sets standards for assessing and improving the energy performance of homes (NJCEP, 2010).

HPwES employs a "house as a system" approach to improving energy efficiency. Each home in the program has an energy audit, which is used to generate a list of prioritized energy efficiency measures and the cost of the measures. The energy audit assesses the home's performance, including:

- A health and safety check (carbon monoxide levels, moisture, and indoor air quality problems)

- Overall comfort level (cold/hot spots, indoor air quality stuffiness/stale odors)

- Air sealing opportunities

- Insulation levels

- Heating system efficiency

- Cooling system/central AC efficiency, if applicable

- Domestic hot water system efficiency.

Once the audit is completed, the contractor uses a proprietary energy modeling software, Real Home Analyzer (RHA), by Conservation Services Group (CSG) to generate a report of recommended energy efficiency measures. The homeowner receives a report listing the recommended measures, and the applicable financial incentives available to implement those measures (NJ Office of Clean Energy, 2013).

\footnotetext{
${ }^{3}$ Utility bill data provided site energy savings percentages, which were then converted to source energy savings using source-site ratios from the U.S. Environmental Protection Agency.
} 
The New Jersey HPwES has three tiers of incentives based on estimated total (site) energy savings (TES) (see Table 1).

Table 1. New Jersey HPwES Requirements and Incentives

\begin{tabular}{|c|c|c|}
\hline Incentive Tier & Requirements & Customer Incentive \\
\hline Tier 1 & $\begin{array}{l}\text { Home assessment/energy audit: to be } \\
\text { eligible for HPwES incentives, a } \\
\text { homeowner must have a home } \\
\text { assessment (audit) performed by a } \\
\text { certified contractor }\end{array}$ & None \\
\hline Tier 2 & $\begin{array}{c}\text { Estimated TES of at least } 10 \% \text { and less } \\
\text { than } 20 \% \\
\text { Must install air sealing } \\
\text { May install insulation and may also } \\
\text { install duct sealing and duct insulation } \\
\text { measures } \\
\text { May include water heater measures }\end{array}$ & $\begin{array}{l}\$ 2,000 \text { rebate, not to exceed } 50 \% \\
\text { of the costs of the eligible } \\
\text { measures used to calculate the TES } \\
\text { And } \\
\text { Up to a } \$ 5,000 \text { loan at } 0 \% \text { where a } \\
\text { utility loan is not available }\end{array}$ \\
\hline Tier 3 Level 1 & $\begin{array}{c}\text { Estimated TES of at least } 20 \% \text { and less } \\
\text { than } 25 \% \\
\text { Must install at least two measures } \\
\text { including air sealing from the eligible } \\
\text { measures list }\end{array}$ & $\begin{array}{l}\$ 4,000 \text { rebate, not to exceed } 50 \% \\
\text { of the costs of the measures used } \\
\text { to calculate TES } \\
\text { And } \\
\text { Up to } \$ 10,000 \text { loan at } 0 \% \text { where a } \\
\text { utility loan is not available }\end{array}$ \\
\hline Tier 3 Level 2 & $\begin{array}{c}\text { Estimated TES of } 25 \% \text { or greater } \\
\text { Must install at least two measures } \\
\text { including air sealing from the eligible } \\
\text { measures list }\end{array}$ & $\begin{array}{c}\$ 5,000 \text { rebate, not to exceed } 50 \% \\
\text { of cost of the measures used to } \\
\text { calculate TES } \\
\text { And } \\
\text { Up to } \$ 10,000 \text { loan at } 0 \% \text { where a } \\
\text { utility loan is not available }\end{array}$ \\
\hline
\end{tabular}

The TES for the tier structure is generated using a proprietary energy modeling software, RHA, by CSG. Actual savings are not verified. For practical reasons, this is typical of the HPwES program nationally. RHA uses 12 months of utility bill data prior to retrofit work to calculate potential energy savings for implemented measures of packages. The user's manual for the New Jersey HPwES RHA modeling states that the thermostat settings are to be kept at their default values (see Table 2).

Table 2. RHA Thermostat Settings (CSG, 2012)

\begin{tabular}{c|c|c}
\hline Heating & Setbacks & Setback Periods \\
\hline $68^{\circ}-74^{\circ} \mathrm{F}$ & $5^{\circ}-10^{\circ} \mathrm{F}$ & $4-12 \mathrm{~h} /$ day, 5 days $/$ week \\
Cooling & Setbacks & Setback Periods \\
$74^{\circ}-80^{\circ} \mathrm{F}$ & $5^{\circ}-10^{\circ} \mathrm{F}$ & $4-12 \mathrm{~h} /$ day, 5 days $/$ week \\
\hline
\end{tabular}

As such, occupant behavior is kept constant for the pre- and post-retrofit model. Also, in the energy model, air sealing can only be included for a maximum 1000 CFM50 reduction (CSG, 
2012). While contractors in the New Jersey program were not surveyed, anecdotal conversations with several suggest that most use the 1000 CFM50 reduction in their models except when working on homes that have inaccessible attics as that is where most of the air sealing work is concentrated.

The accuracy of energy modeling varies widely, and for existing homes inaccuracies may be greater. This is often attributed to energy modeling software over predicting energy use prior to retrofit work and consequently overstating post-retrofit savings (Polly, Kruis, \& Roberts, 2011). The advantage of RHA is that 12 months of pre-retrofit utility data are put into each home's energy model, so that pre-retrofit energy use is not over predicted. This research investigated the actual change in site energy use following the installation of recommended energy efficiency measures by comparing pre- and post-retrofit utility data to determine which package(s) of energy efficiency measures deliver actual site savings of $30 \%$ or more. BARA then converted site savings to source energy savings for comparison to the BA goal of $30 \%$ source energy savings.

New Jersey HPwES maintains an eligible measures list (referenced in the incentive requirements) to ensure that incentivized heating, ventilation, and air conditioning (HVAC) system and shell improvements meet minimum efficiency and quality control standards. Table 3 summarizes the eligible measures. ${ }^{4}$

Table 3. Summarized New Jersey HPwES Eligible Measures List (NJ Office of Clean Energy, 2012)

\begin{tabular}{|c|c|}
\hline Item & Minimum Requirement(s) \\
\hline \multicolumn{2}{|c|}{ Primary Heating System } \\
\hline Furnace-Natural Gas/Propane & $\mathrm{AFUE}^{\mathrm{a}} 92 \%$ \\
\hline Furnace-Oil & AFUE $85 \%$ \\
\hline $\begin{array}{c}\text { Boiler-Hot Water-Natural } \\
\text { Gas/Propane/Oil }\end{array}$ & AFUE $85 \%$ \\
\hline Boiler-Steam—Natural Gas/Propane/Oil & AFUE $82 \%$ \\
\hline Air Source Heat Pump (Electric Split System) & 12.0 $\mathrm{EER}^{\mathrm{b}} / 14.5 \mathrm{SEER}^{\mathrm{c}} / 8.5 \mathrm{HSPF}^{\mathrm{d}}$ \\
\hline $\begin{array}{c}\text { Air Source Heat Pump } \\
\text { (Mini/Central Split System) }\end{array}$ & $1.2 \mathrm{COP}^{\mathrm{e}}(\mathrm{h}) / 1.25 \mathrm{COP}(\mathrm{c})$ \\
\hline Ground Source Heat Pump & 14.1 EER/3.3 COP \\
\hline \multicolumn{2}{|c|}{ Cooling Equipment } \\
\hline AC (Mini/Central Split System) & 14.5 SEER/12.0 EER \\
\hline \multicolumn{2}{|c|}{ Ducted Distribution System } \\
\hline Duct Sealing & $\begin{array}{l}\text { Underwriters Laboratories } 181 \mathrm{~B} \text { mastic; tape } \\
\text { is disallowed, submit pre- and post-leak } \\
\text { testing }\end{array}$ \\
\hline
\end{tabular}

\footnotetext{
${ }^{4}$ Note: other requirements associated with these measures can be seen with the full listing at http://www.njcleanenergy.com/files/file/Residential\%20Programs/HP/Contractor\%20Portal\%20Documents/2.11.13/ 2013\%20NJ\%20HPwES\%20Eligible\%20Measures\%20with\%20SEP\%20Oil-PropaneMuniElectric $\% 20$ SEP\%20Funding\%2001_23_13.pdf.
} 


\begin{tabular}{|c|c|}
\hline Item & Minimum Requirement(s) \\
\hline Duct Insulation & $\begin{array}{l}\text { R-8 supplies in attics, all other R-6 (except } \\
\text { ducts inside thermal envelope) }\end{array}$ \\
\hline \multicolumn{2}{|c|}{ Water Heater } \\
\hline Tank-Natural Gas/Propane & $\begin{array}{c}\mathrm{EF}^{\mathrm{f}} 0.62 \text { power vent } \\
\text { (i.e., positive vent pressure) }\end{array}$ \\
\hline On-Demand-Natural Gas/Propane & EF 0.82 (instantaneous water heaters) \\
\hline Indirect-Fired Tank & With qualifying boiler, min. 30 gal, R-16 \\
\hline Heat Pump Water Heaters & $\mathrm{EF} \geq 2.0$ \\
\hline \multicolumn{2}{|c|}{ Building Shell } \\
\hline Insulation (if proposing an upgrade) & NJ State code and efficiency requirement \\
\hline $\begin{array}{l}\text { Attic Floor or Roof Deck } \\
\text { (may not be combined) }\end{array}$ & $\mathrm{R}-38$ \\
\hline Walls_-Above Grade, Band Joists & $\mathrm{R}-13$ \\
\hline Floors & R-19 \\
\hline Foundation Walls_-Basement, Crawlspace & $\mathrm{R}-10$ \\
\hline Air Sealing & $\begin{array}{l}\text { Conducted by BPI contractor with pre- } \\
\text { and post-blower door testing }\end{array}$ \\
\hline \multicolumn{2}{|c|}{ Mechanical Ventilation } \\
\hline Exhaust Ventilation Fans & $\begin{array}{c}\text { ENERGY STAR Qualified } \\
\text { (must vent to exterior of building shell) }\end{array}$ \\
\hline Heat/Energy Recovery Ventilator & No minimum efficiency requirement \\
\hline $\begin{array}{c}\text { HVAC Integrated With Fan Control and } \\
\text { Mechanical Damper }\end{array}$ & $\begin{array}{l}\text { Installed with qualifying furnace with } \\
\text { electronically commutated motor }\end{array}$ \\
\hline \multicolumn{2}{|c|}{ Health and Safety Measures } \\
\hline Smoke, Radon, Carbon Monoxide Detector & $\begin{array}{l}\text { These measures can be either hard wired or } \\
\text { battery operated }\end{array}$ \\
\hline $\begin{array}{c}\text { Repairs/Upgrades to Venting Systems and } \\
\text { Power Venting Kits }\end{array}$ & $\begin{array}{l}\text { Per code and/or manufacturer specifications } \\
\text { as appropriate }\end{array}$ \\
\hline $\begin{array}{c}\text { Measures To Provide Sufficient Combustion } \\
\text { Air and Prevent Combustion Appliance Zone } \\
\text { Depressurization, Spillage, or Inadequate } \\
\text { Draft }\end{array}$ & $\begin{array}{l}\text { Allowed when BPI required combustion } \\
\text { safety tests indicate problem(s) with } \\
\text { combustion appliance zone depressurization, } \\
\text { draft or spillage, per BPI standards }\end{array}$ \\
\hline Vapor Barriers & Minimum 6-mil plastic \\
\hline Attic Ventilation & Passive ventilation only \\
\hline Fuel Line Leak Repairs & Permanent repairs \\
\hline Clothes Dryer Venting & $\begin{array}{l}\text { At least semi-rigid metal, vented to outside, } \\
\text { R-7 in unconditioned space }\end{array}$ \\
\hline Exhaust Fan Venting & $\begin{array}{l}\text { Vented to outside, pitched up to outside, R-7 } \\
\text { in unconditioned space }\end{array}$ \\
\hline
\end{tabular}

${ }^{a}$ Annual fuel utilization efficiency

${ }^{b}$ Energy efficiency ratio

${ }^{c}$ Seasonal energy efficiency ratio

${ }^{\mathrm{d}}$ Heating season performance factor

${ }^{\mathrm{e}}$ Coefficient of performance

${ }^{\mathrm{f}}$ Energy factor 


\section{Tier 3 Level 2, Forty-Two Homes}

This research focused on homes in the 2011 New Jersey HPwES program that had estimated TES of $25 \%$ or more. Selection of the 2011 program year allowed for the collection of a full 12 months of utility data after program participation. The site energy savings threshold of at least $25 \%$ corresponds to the program's top tier of savings (tier 3 level 2) and was anticipated to approach the BA goal of a $30 \%$ source energy use reduction in homes. These criteria produced a list of 42 tier 3 level 2 homes from the 2011 program.

Originally, actual audit sheets for each home were pursued, but, because of the New Jersey Office of Clean Energy's requirement for program participant privacy through data redaction, only the tracking spreadsheet for the homes was available. Data points on the spreadsheet did not include existing insulation levels for homes where insulation was installed. Despite this, it was confirmed with the New Jersey HPwES program director that in most cases there was no existing insulation when wall insulation was installed and that when attic floor insulation was installed it was usually over some level of insulation well below code requirements.

Among the 42 tier 3 level 2 homes:

- Modeled TES ranged from 25\%-42\%, with an average of $29 \%$.

- Total project costs ranged from $\$ 3,645-\$ 35,860$, with an average of $\$ 14,082$.

\subsection{Implemented Measures}

All 42 homes were air sealed, as is required by the program. The next most common measure was heating system replacement (39 homes) followed by insulation of the attic hatch or attic stair (32 homes), installation of central AC (31 homes), insulation of the attic floor or living space ceiling (31 homes), water heater replacement (31 homes), insulation of walls (14 homes), and duct insulation (1 home). The implemented measures are shown Table 4.

Table 4. Energy Conservation Measures Implemented in 42 Tier 3 Level 2 New Jersey HPwES Homes

\begin{tabular}{c|c|c}
\hline Energy Conservation Measure & $\begin{array}{c}\text { Number of } \\
\text { Homes }\end{array}$ & $\begin{array}{c}\text { Percentage of the } \\
\mathbf{4 2} \text { Homes }\end{array}$ \\
\hline Air Sealing & 42 & $100 \%$ \\
\hline Replace Heating System & 39 & $93 \%$ \\
\hline Insulate Attic Hatch & 32 & $76 \%$ \\
\hline Install Central AC & 31 & $74 \%$ \\
\hline Insulate Attic Floor & 31 & $74 \%$ \\
\hline Replace Water Heater & 30 & $71 \%$ \\
\hline Insulate Walls & 14 & $33 \%$ \\
\hline Insulate Ducts & 1 & $2 \%$ \\
\hline
\end{tabular}

\subsubsection{Air Sealing-Forty-Two Homes}

Blower door testing of the 42 homes showed a range of 1688 CFM50 to 5742 CFM50, a roughly fourfold difference from low to high, with an average of 3138 CFM50 (Figure 3). 


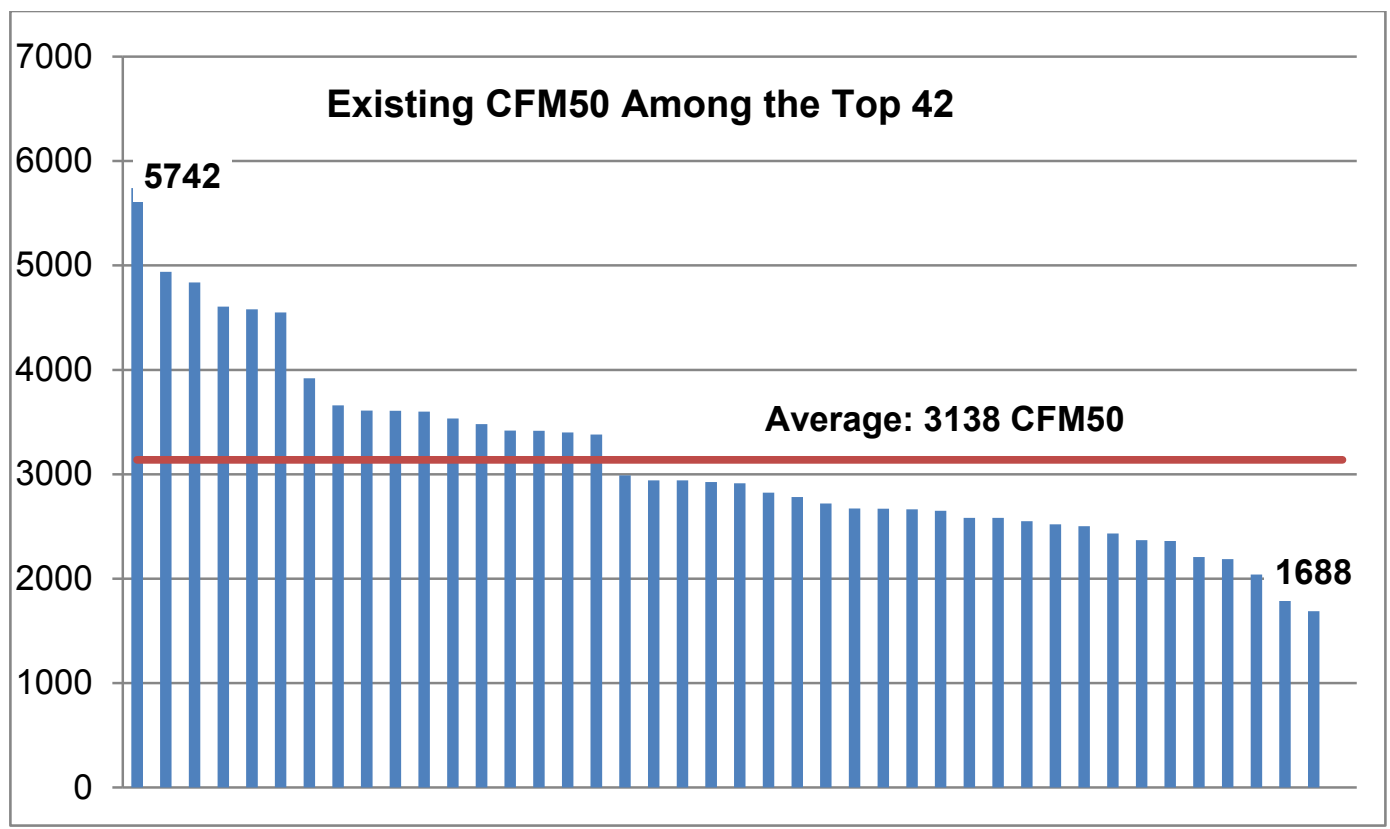

Figure 3. Existing CFM50 among 42 tier 3 level 2 homes

When calculated as air changes per hour based on home volume, results range from a low of 6.4 $\mathrm{ACH} 50$ to a high of 25.0 ACH50 with an average of $13.8 \mathrm{ACH} 50$ (Figure 4).

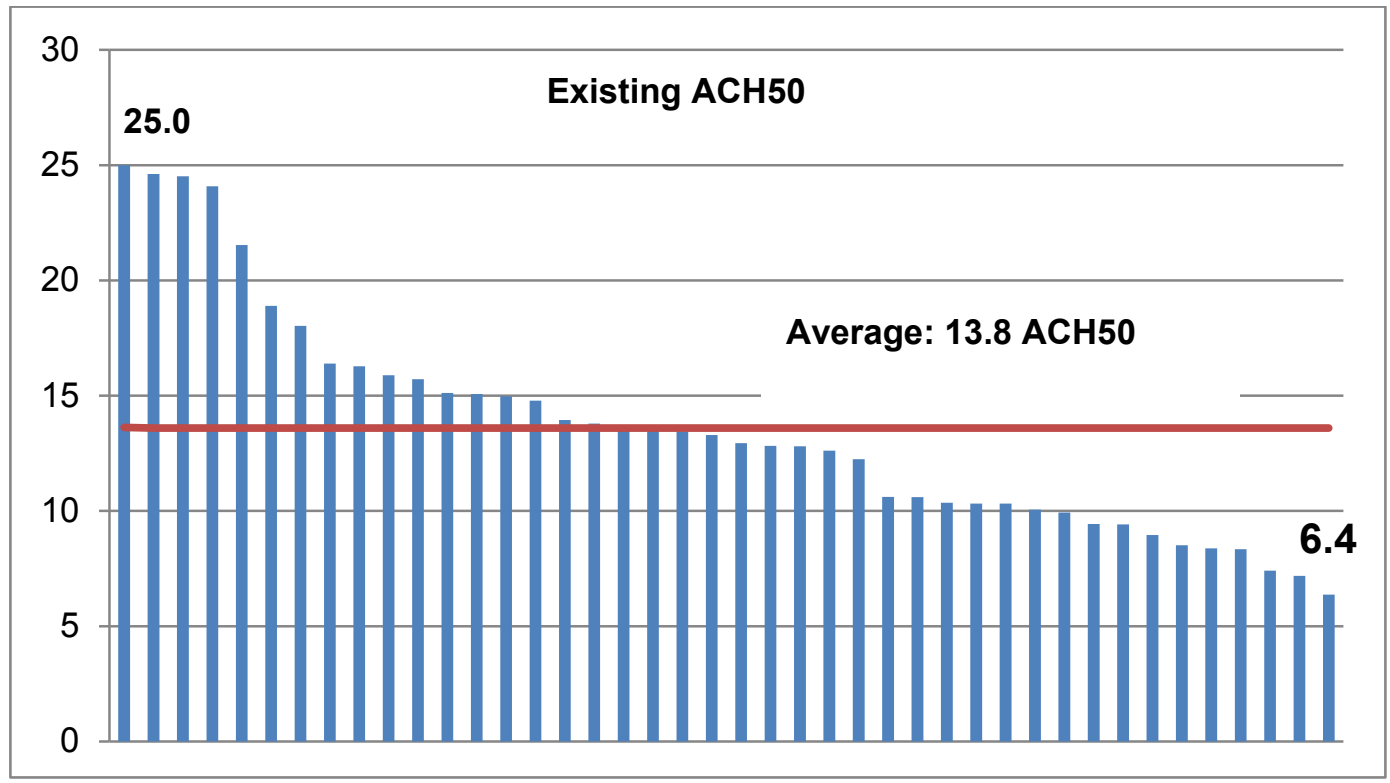

Figure 4. Existing ACH50 among 42 tier 3 level 2 homes

Air sealing measures in the homes typically include air sealing in the attic and basement or crawlspace. Attics are air sealed at top plates, vent stacks, plumbing and electrical penetrations, attic access points, and at ductwork penetrations and chases. Basements or crawlspaces are typically sealed at the sill plate, the rim joist and at floor penetrations. 
Post-air sealing blower door tests show a low of 1046 CFM50 to a high of 5164 CFM50 and an average of 2423 CFM50 (Figure 5). The average reduction was 715 CFM50, or a $24 \%$ reduction. This is below the 1000 CFM50 reduction allowed as the maximum reduction within RHA.

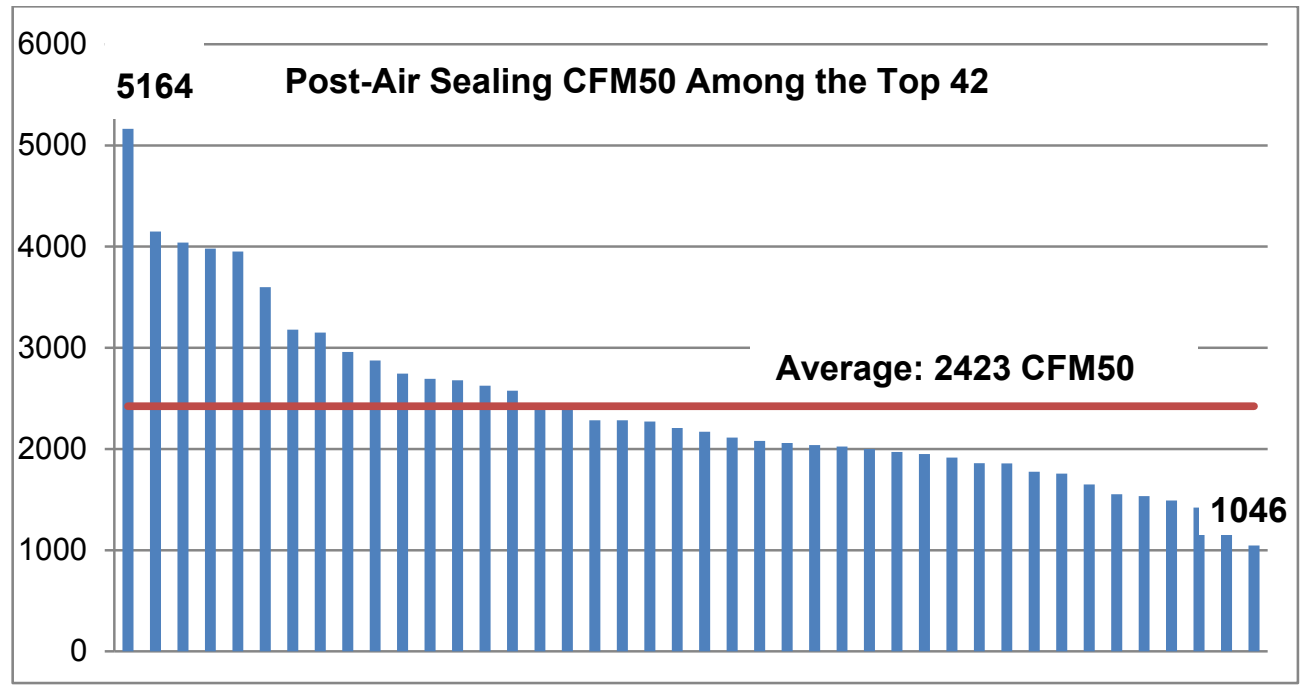

Figure 5. Post-air sealing CFM50 among 42 tier 3 level 2 homes

When converted to ACH50, there is a low of $4.8 \mathrm{ACH} 50$ and a high of $20.4 \mathrm{ACH} 50$, with an average of 10.4 ACH50 (Figure 6).

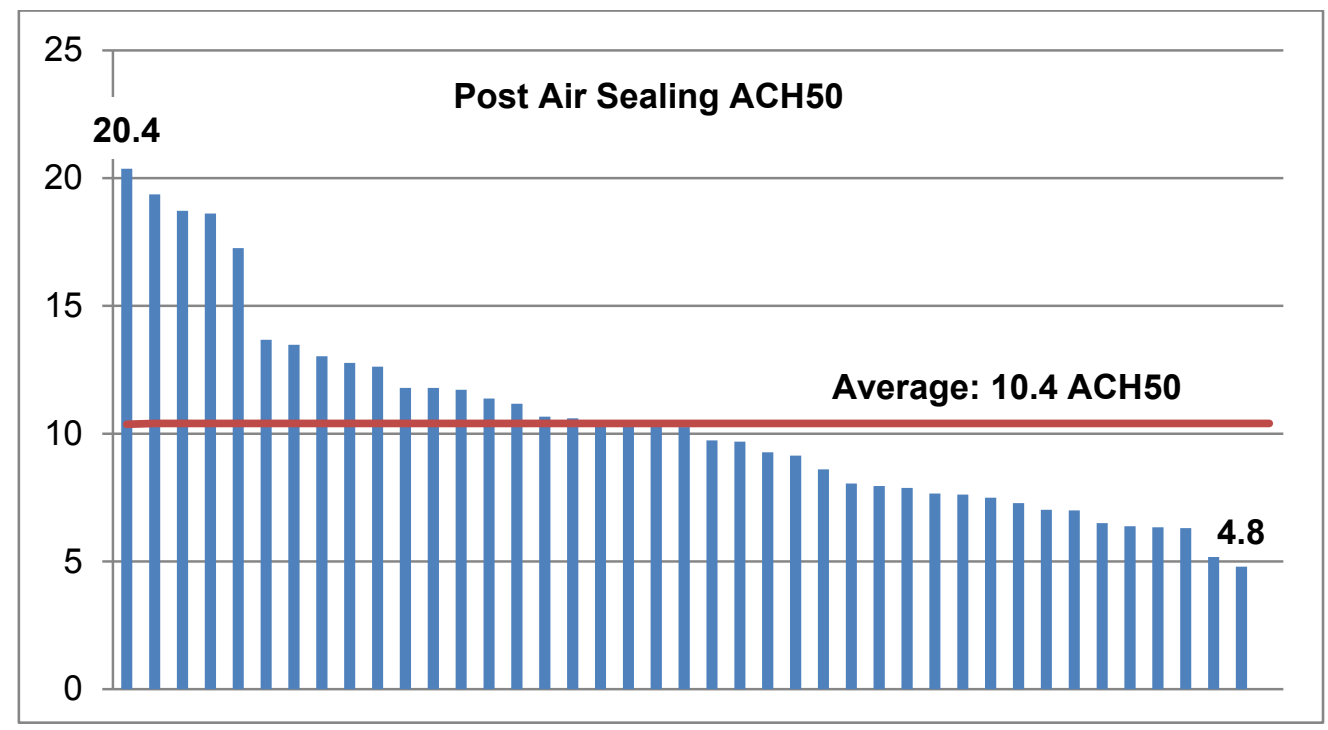

Figure 6. Post air sealing ACH50 among 42 tier 3 level 2 homes

More than half the homes have greater than $10 \mathrm{ACH} 50$ post-air sealing, suggesting that there is more potential for energy use reduction through air sealing in these homes (Figure 7). 


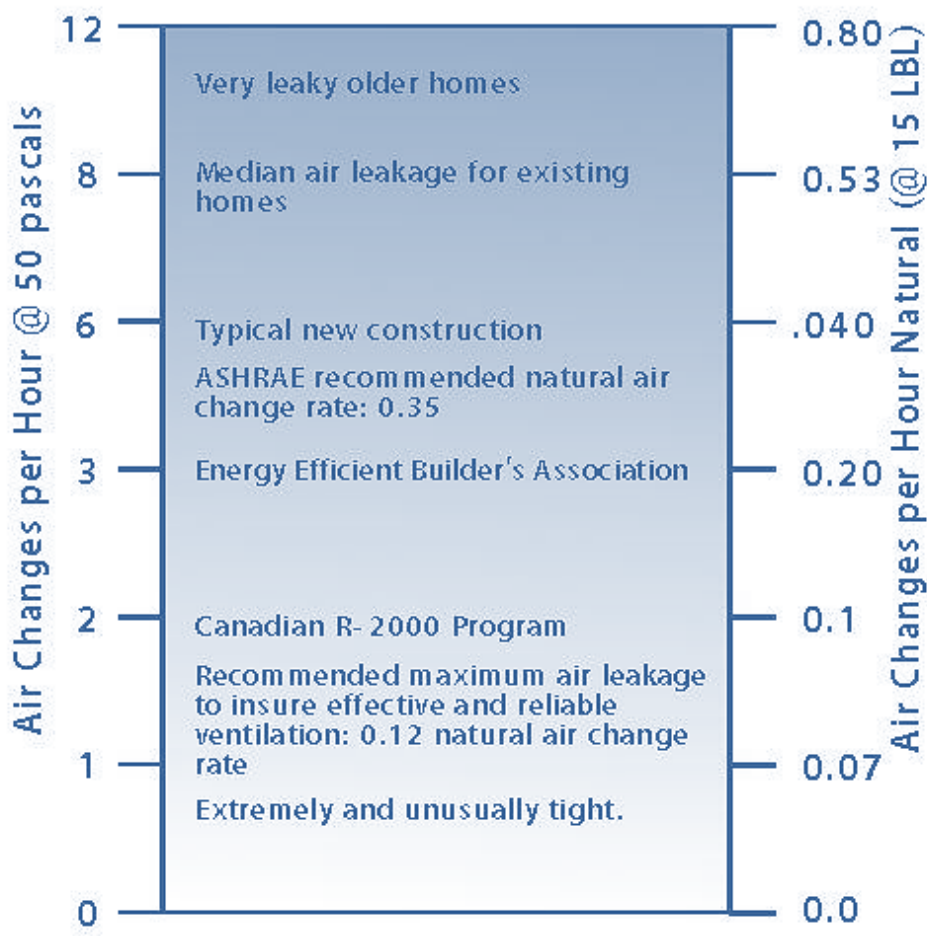

Figure 7. Blower door result guidelines (Krigger \& Dorsi, 2009)

(Used with permission from John Krigger)

As shown in the blower door result guidelines, air leakage greater than about 11 ACH50 is considered to be found in "Very leaky older homes." Among the 42 HPwES homes, 15 had an $\mathrm{ACH} 50$ of 11 or higher and 21 had an ACH50 of 10 or higher, after air sealing work was done.

When the building airflow standard (BAS) (BPI, 2005) was calculated for each of the 42 homes, it was found that all the homes could have been tightened at least another 500 CFM50 and not reached their BAS. On average the post-retrofit blower door reading was 715 CFM higher than the BAS. This suggests that a fair amount of potential envelope improvement through air sealing is being left on the table. This may be for a variety of reasons, including a reluctance to require mechanical ventilation and the difficulty of air sealing houses in some cases.

\subsubsection{Heating System Replacement-Thirty-Nine Homes}

The next most common energy conservation measure among the 42 homes was heating system replacement, completed in 39 homes. The majority of these 39 homes had furnaces with efficiencies in the 70s as shown in Table 5. Twenty-four of the 39 homes had 95 AFUE gas furnaces installed. 
Table 5. Existing Heating Systems Among 39 Homes With Heating System Replacement

\begin{tabular}{|c|c}
\hline Existing Heating System & $\begin{array}{c}\text { Number of Homes } \\
\text { With This System }\end{array}$ \\
\hline Electric resistance heat & 3 \\
$\mathbf{0 . 7 0}$ AFUE Boiler & 3 \\
$\mathbf{0 . 7 1}$ AFUE Furnace & 20 \\
$\mathbf{0 . 7 3}$ AFUE Furnace & 1 \\
0.74 AFUE Furnace & 5 \\
0.74 AFUE Boiler & 1 \\
0.74 AFUE Furnace & 1 \\
0.75 AFUE Boiler & 1 \\
0.80 AFUE Furnace & 2 \\
$\mathbf{0 . 8 2}$ AFUE Furnace & 1 \\
$\mathbf{0 . 9 0}$ AFUE Furnace & 1 \\
\hline
\end{tabular}

Table 6. Replacement Heating Systems Among 39 Homes With Heating System Replacement

\begin{tabular}{|c|c|}
\hline Replacement Heating Systems & $\begin{array}{c}\text { Number of Homes } \\
\text { With This System }\end{array}$ \\
\hline 0.85 AFUE Furnace & 1 \\
0.91 AFUE Boiler & 1 \\
0.92 AFUE Furnace & 1 \\
0.95 AFUE Furnace & 24 \\
0.95 AFUE Boiler & 4 \\
0.96 AFUE Furnace & 4 \\
8.9 HSPF Heat Pump & 1 \\
9.0 HSPF Heat Pump & 1 \\
9.2 HSPF Heat Pump & 1 \\
4.4 COP Ground Source Heat Pump & 1 \\
\hline
\end{tabular}

\subsubsection{Attic Access Insulation-Thirty-Two Homes}

Twenty-one homes had R-19 insulation added to their attic access hatches. Eleven homes had R14 attic stair covers installed.

\subsubsection{Installation of Central Air Conditioning-31 Homes}

Thirty-one homes had central AC installed (see Table 7).

Table 7. Existing Central AC Systems Among 31 Homes With Central AC Installation

\begin{tabular}{c|c}
\hline Existing Central AC System & $\begin{array}{c}\text { Number of Homes } \\
\text { With This System }\end{array}$ \\
\hline 8 SEER & 3 \\
8.7 SEER & 2 \\
9.4 SEER & 1 \\
10 SEER & 6 \\
No Central AC & 19 \\
\hline
\end{tabular}

\footnotetext{
${ }^{5}$ This furnace was replaced with a 4.4 COP ground source heat pump.
} 
As shown, 19 of the 31 homes that had central AC installed as part of their retrofits did not have existing central AC. Interestingly, this has been an issue for public housing programs where public housing authorities are attempting to reduce electricity use by upgrading window AC. What happens is that many people who do not have window units opt in for the new units, and ultimately overall electricity use goes up. For those homes introducing central AC, we would expect kilowatt-hour usage to go up.

Table 8. New Central AC System Efficiency Among 31 Homes With Central AC Installation

\begin{tabular}{c|c}
\hline New Central AC System Efficiency & $\begin{array}{c}\text { Number of Homes } \\
\text { With This System }\end{array}$ \\
\hline 14.5 SEER & 3 \\
15 SEER & 4 \\
15.5 SEER & 3 \\
16 SEER & 13 \\
16.5 SEER & 2 \\
17.5 SEER & 3 \\
18 SEER & 1 \\
18.5 SEER & 1 \\
19 SEER & 1 \\
\hline
\end{tabular}

Thirteen homes had SEER 16 AC installed. Efficiency ranged from a high of SEER 19 in one home to a low of SEER 14.5 in three homes.

\subsubsection{Floor/Ceiling Insulation-Thirty-One Homes}

Thirty-one homes had attic floor/living space ceiling insulation installed. The most common measure was to add 6 in. of insulation to the attic floor.

Table 9. Added Attic Floor Insulation Among 31 Homes

\begin{tabular}{c|c}
\hline Added Attic Floor Insulation & $\begin{array}{c}\text { Number of Homes } \\
\text { With This Insulation }\end{array}$ \\
\hline $\mathbf{2}$ in. Polyisocyanurate & $2^{6}$ \\
$\mathbf{4}$ in. Blown-In Fibrous Insulation & 3 \\
$\mathbf{5}$ in. Blown-In Fibrous Insulation & 10 \\
$\mathbf{6}$ in. Blown-In Fibrous Insulation & 4 \\
$\mathbf{8}$ in. Blown-In Fibrous Insulation & 2 \\
\hline $\mathbf{9}$ in. Blown-In Fibrous Insulation & 4 \\
$\mathbf{1 0}$ in. Blown-In Fibrous Insulation & 1 \\
$\mathbf{1 2}$ in. Blown-In Fibrous Insulation & 1 \\
$\mathbf{1 3}$ in. Blown-In Fibrous Insulation & 3 \\
\hline $\mathbf{1 4}$ in. Blown-In Fibrous Insulation & 1 \\
\hline
\end{tabular}

\footnotetext{
${ }^{6}$ One of these houses also has 6 in. blown in fibrous insulation, as such the table total is 32 , but the house total is 31
} houses. 


\subsubsection{Water Heater Replacement-Thirty Homes}

Thirty homes had their water heaters replaced, with 13 getting 0.63 EF storage water heaters. Ten homes had tankless water heaters installed, ranging from $0.82 \mathrm{EF}$ to $0.96 \mathrm{EF}$.

Table 10. Replacement Water Heaters Among 30 Homes

\begin{tabular}{|c|c}
\hline Replacement Water Heater & $\begin{array}{c}\text { Number of Homes With This } \\
\text { Type Water Heater }\end{array}$ \\
\hline 0.62 EF Storage & 3 \\
0.63 EF Storage & 13 \\
0.64 EF Storage & 1 \\
0.82 EF Tankless & 1 \\
0.84 EF Indirect & 1 \\
0.87 EF Tankless & 3 \\
0.88 EF Indirect & 1 \\
0.93 EF Electric & 1 \\
0.94 EF Tankless & 2 \\
0.95 EF Tankless & 1 \\
0.96 EF Tankless & 3 \\
\hline
\end{tabular}

\subsubsection{Wall Insulation-Fifteen Homes}

Fifteen of the 42 homes had wall insulation installed, with nine getting some level of insulation in the attic kneewalls, six having their basement rim joists insulated, and two getting insulation on the basement walls. Four homes had more than one type of wall insulation installed, accounting for the tally of 19 in Table 11.

Table 11. Wall Insulation Installed in 15 Homes

\begin{tabular}{|c|c|}
\hline Wall Insulation & $\begin{array}{c}\text { Number of Homes With This } \\
\text { Wall Insulation }\end{array}$ \\
\hline R-5 Attic Kneewall & 1 \\
R-15 Attic Kneewall & 2 \\
R-20 Attic Kneewall & 5 \\
R-30 Attic Kneewall & 1 \\
R-19 Basement Rim Joist & 6 \\
R-20 Basement Rim Joist & 1 \\
R-11 Above-Grade Dense Pack Wall & 1 \\
R-10 Basement Wall & 1 \\
R-13 Basement Wall & 1 \\
\hline
\end{tabular}

\subsubsection{Duct Insulation-One Home}

Surprisingly, only one home had duct insulation installed.

\subsection{Implemented Packages of Measures}

Among the 42 homes, there were 16 unique packages of the eight measures installed. The most common package of measures included air sealing, heating system replacement, insulation of attic access, central AC, attic floor insulation, and water heater replacement. This package was 
implemented in 11 homes. The range of packages and number of homes with each package are shown in Table 12.

Table 12. Sixteen Package Combinations Among 42 Homes

\begin{tabular}{|c|c|c|c|c|c|c|c|c|c|c|c|c|c|c|c|c|}
\hline Packages & $\mathbf{A}$ & B & $\mathrm{C}$ & D & $\mathbf{E}$ & $\mathrm{F}^{*}$ & $\mathbf{G}$ & $\mathbf{H}$ & I & $\mathbf{J}$ & $\mathbf{K}$ & $\mathbf{L}$ & $\mathbf{M}$ & $\mathbf{N}$ & $\mathbf{O}$ & $\mathbf{P}$ \\
\hline Air Seal & $\mathrm{x}$ & $\mathrm{x}$ & $\mathrm{x}$ & $\mathrm{x}$ & $\mathrm{x}$ & $\mathrm{x}$ & $\mathrm{x}$ & $\mathrm{x}$ & $\mathrm{x}$ & $\mathrm{x}$ & $\mathrm{x}$ & $\mathrm{x}$ & $\mathrm{x}$ & $\mathrm{x}$ & $\mathrm{X}$ & $\mathrm{x}$ \\
\hline Heating & $\mathrm{x}$ & $\mathrm{x}$ & $\mathrm{x}$ & $\mathrm{x}$ & $\mathrm{x}$ & $\mathrm{x}$ & $\mathrm{x}$ & $\mathrm{x}$ & $\mathrm{x}$ & $\mathrm{x}$ & $\mathrm{x}$ & $\mathrm{X}$ & $\mathrm{x}$ & $\mathrm{X}$ & & \\
\hline Hatch & $\mathrm{x}$ & $\mathrm{x}$ & $\mathrm{x}$ & & $\mathrm{x}$ & & $\mathrm{x}$ & & & $\mathrm{x}$ & $\mathrm{x}$ & $\mathrm{x}$ & & & $\mathrm{x}$ & $\mathrm{x}$ \\
\hline $\mathrm{AC}$ & $\mathrm{x}$ & & & $\mathrm{x}$ & $\mathrm{x}$ & $\mathrm{x}$ & & $\mathrm{x}$ & $\mathrm{x}$ & $\mathrm{x}$ & $\mathrm{x}$ & $\mathrm{x}$ & $\mathrm{x}$ & & & \\
\hline Floor & $\mathrm{x}$ & $\mathrm{x}$ & $\mathrm{x}$ & $\mathrm{x}$ & & & $\mathrm{x}$ & & & $\mathrm{x}$ & $\mathrm{x}$ & & & & $\mathrm{x}$ & $\mathrm{x}$ \\
\hline DHW & $\mathrm{x}$ & & $\mathrm{x}$ & $\mathrm{x}$ & & & $\mathrm{x}$ & $\mathrm{x}$ & $\mathrm{x}$ & & $\mathrm{x}$ & $\mathrm{x}$ & $\mathrm{x}$ & $\mathrm{x}$ & $\mathrm{x}$ & \\
\hline Wall & & $\mathrm{x}$ & $\mathrm{x}$ & & & & & & $\mathrm{x}$ & & $\mathrm{x}$ & $\mathrm{x}$ & & & $\mathrm{x}$ & $\mathrm{x}$ \\
\hline Duct Insulation & & & & & & & & & & & & & $\mathrm{x}$ & & & \\
\hline Total Houses & 11 & 5 & 2 & 3 & 2 & 2 & 4 & 1 & 2 & 2 & 2 & 1 & 1 & 1 & 2 & 1 \\
\hline
\end{tabular}

Only three homes among the 42 did not have heating or cooling replacement. These homes had projected savings of $42 \%, 29.9 \%$, and $26.7 \%$ with an average projected savings of $32.9 \%$. The average savings of the other 39 projects was $28.9 \%$. The nonheating and cooling homes project costs were $\$ 6,351$ (Wharton), $\$ 14,980$ (Fanwood), and \$3,645 (Delran) with an average of $\$ 8,325$. The average cost among the remaining 39 homes was $\$ 14,806$. 


\section{Tier 3 Level 2 Homes With Utility Data-Seventeen Homes}

Utility bill data were sought for the 42 homes discussed. Eighteen of the 42 homeowners contacted chose to participate in the research and signed a utility bill release form, allowing access to their utility bill data. One of the eighteen did not have the required data available and was omitted from further analysis. Three homes among the 17 did not have heating or cooling equipment installed. These are the Wharton, Fanwood, and Delran homes. These three homes are treated as a subgroup in Table 13 to allow for a comparison between the non-HVAC and HVAC packages, as well as all the individual home packages. 
Table 13. Installed Energy Conservation Measures in Tier 3 Level 2 Homes with Utility Data

\begin{tabular}{|c|c|c|c|c|c|c|c|}
\hline \multirow{3}{*}{ 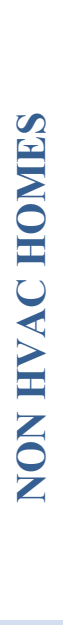 } & $\begin{array}{l}\text { House } \\
\text { Location }\end{array}$ & $\begin{array}{l}\text { Conditioned } \\
\text { Space }\end{array}$ & Volume & $\begin{array}{l}\text { Infiltration } \\
\text { Reduction } \\
\text { (CFM50) }\end{array}$ & $\begin{array}{c}\text { HVAC and DHW } \\
\text { Measures }\end{array}$ & $\begin{array}{l}\text { Roof/Attic } \\
\text { Measure } \\
\text { (Installed } \\
\text { R-Value) } \\
\end{array}$ & Wall Insulation \\
\hline & Wharton & 925 & 6,656 & 805 & $0.64 \mathrm{EF}$ water heater & $\begin{array}{l}10 \text { in. cellulose } \\
\text { insulation attic } \\
\text { floor }\end{array}$ & $\begin{array}{c}6 \text { in. fiberglass bat on rim } \\
\text { joist } 4 \text { in. dense pack } \\
\text { cellulose above grade } \\
\text { walls }\end{array}$ \\
\hline & Fanwood & 2,202 & 18,534 & 942 & $\begin{array}{c}0.95 \mathrm{EF} \text { tankless water } \\
\text { heater }\end{array}$ & $\begin{array}{l}10 \text { in. cellulose } \\
\text { insulation attic } \\
\text { floor, } 10 \text { in. dense } \\
\text { pack cellulose in } \\
\text { garage ceiling }\end{array}$ & $\begin{array}{c}2 \text { in. rigid insul. } \\
\text { basement wall } \\
6 \text { in. batt attic kneewall }\end{array}$ \\
\hline \multirow{7}{*}{ 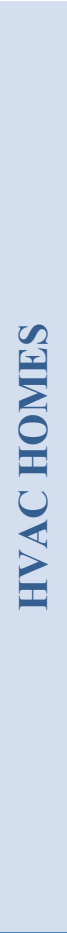 } & Delran & 1,848 & 14,784 & 653 & N/A & $\begin{array}{l}6 \text { in. cellulose attic } \\
\text { floor }\end{array}$ & 3.5 in. batt basement wall \\
\hline & Freehold & 2,080 & 16,640 & 603 & $\begin{array}{c}16 \text { SEER AC } \\
95 \text { AFUE gas furnace }\end{array}$ & $\begin{array}{l}6 \text { in. cellulose attic } \\
\text { floor }\end{array}$ & $\begin{array}{l}1 \text { in. rigid insul. attic } \\
\text { kneewall }\end{array}$ \\
\hline & Edison & 1,059 & 8,470 & 525 & $\begin{array}{c}0.85 \mathrm{EF} \text { oil furnace } \\
0.93 \mathrm{EF} \text { electric water } \\
\text { heater }\end{array}$ & $\begin{array}{c}6 \text { in. cellulose } \\
\text { insulation for attic } \\
\text { floor }\end{array}$ & N/A \\
\hline & Mahwah & 1,870 & 14,960 & 842 & $\begin{array}{l}95 \text { AFUE gas furnace } \\
19 \text { SEER AC } \\
0.63 \text { EF water heater }\end{array}$ & $\begin{array}{l}6 \text { in. cellulose } \\
\text { insulation for attic } \\
\text { floor }\end{array}$ & N/A \\
\hline & Toms River & 1,027 & 8,730 & 876 & $\begin{array}{l}92 \text { AFUE gas furnace } \\
16 \text { SEER AC } \\
0.62 \text { EF water heater }\end{array}$ & N/A & N/A \\
\hline & Woodbury & 1,560 & 12,480 & 639 & $\begin{array}{l}95 \text { AFUE gas furnace } \\
16 \text { SEER AC } \\
0.62 \text { EF water heater }\end{array}$ & $\begin{array}{l}5 \text { in. fiberglass } \\
\text { attic floor }\end{array}$ & $\begin{array}{l}3 " \text { fiberglass, } 2 \text { in. rigid } \\
\text { insul. attic kneewall }\end{array}$ \\
\hline & Boonton & 2,000 & 16,000 & 578 & $\begin{array}{l}95 \text { AFUE gas boiler } \\
87 \text { EF indirect water } \\
\text { heater. }\end{array}$ & $\begin{array}{l}6 \text { in. cellulose attic } \\
\text { floor }\end{array}$ & N/A \\
\hline
\end{tabular}




\begin{tabular}{|c|c|c|c|c|c|c|c|}
\hline 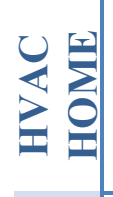 & $\begin{array}{l}\text { House } \\
\text { Location }\end{array}$ & $\begin{array}{l}\text { Conditioned } \\
\text { Space }\end{array}$ & Volume & $\begin{array}{l}\text { Infiltration } \\
\text { Reduction } \\
\text { (CFM50) }\end{array}$ & $\begin{array}{c}\text { HVAC and DHW } \\
\text { Measures }\end{array}$ & $\begin{array}{l}\text { Roof/Attic } \\
\text { Measure } \\
\text { (Installed } \\
\text { R-Value) }\end{array}$ & Wall Insulation \\
\hline & Sewell & 1,439 & 11,512 & 551 & $\begin{array}{l}95 \text { AFUE gas furnace } \\
0.62 \mathrm{EF} \text { water heater }\end{array}$ & $\begin{array}{l}8 \text { in. cellulose attic } \\
\text { floor }\end{array}$ & N/A \\
\hline & Skillman & 2,682 & 21,456 & 610 & $\begin{array}{l}95 \text { AFUE gas furnace } \\
\text { 17.5 SEER AC }\end{array}$ & $\begin{array}{l}8 \text { in. cellulose attic } \\
\text { floor }\end{array}$ & 2 in. spray foam rim joist \\
\hline & Springfield & 1,512 & 12,096 & 667 & $\begin{array}{l}96 \text { AFUE gas furnace } \\
\text { 14.5 SEER AC }\end{array}$ & $\begin{array}{l}14 \text { in. fiberglass } \\
\text { attic floor }\end{array}$ & $\begin{array}{l}2 \text { in. rigid insul. attic } \\
\text { kneewall }\end{array}$ \\
\hline & Brick & 2,688 & 21,054 & 870 & $\begin{array}{l}95 \text { AFUE gas furnace } \\
\text { 14.5 SEER AC }\end{array}$ & $\begin{array}{l}10 \text { in. cellulose } \\
\text { attic floor }\end{array}$ & $\begin{array}{l}2 \text { in. rigid insul. attic } \\
\text { kneewall }\end{array}$ \\
\hline & Augusta & 2,712 & 23,496 & 789 & $\begin{array}{l}95 \text { AFUE hydronic } \\
\text { propane boiler } \\
0.88 \text { EF indirect water } \\
\text { heater } \\
\text { 16 SEER AC }\end{array}$ & $\begin{array}{c}8 \text { in. cellulose attic } \\
\text { floor } \\
\text { R14 attic stair } \\
\text { cover }\end{array}$ & 1 in. rigid attic kneewall \\
\hline & Sicklerville & 9,10 & 7,280 & 766 & $\begin{array}{l}95 \text { AFUE gas furnace } \\
0.63 \text { EF gas DHW }\end{array}$ & $\begin{array}{l}13 \text { in. fiberglass on } \\
\text { attic floor } \\
\text { Insulate attic hatch } \\
\text { R19 }\end{array}$ & NA \\
\hline & Glassboro & 1,768 & 14,144 & 575 & $\begin{array}{l}95 \text { AFUE gas furnace } \\
16 \text { SEER AC }\end{array}$ & $\begin{array}{c}6 \text { in. cellulose } \\
\text { insulation for attic } \\
\text { floor } \\
\text { Insulate attic hatch } \\
\text { R19 }\end{array}$ & N/A \\
\hline & Manchester & 1,267 & 10,136 & 608 & $\begin{array}{c}\text { Air source heat pump } \\
\text { HSPF } 9 \\
\text { SEER } 15\end{array}$ & $\begin{array}{l}\text { R14 attic stair } \\
\text { cover }\end{array}$ & N/A \\
\hline
\end{tabular}




\section{Pre- and Post-Retrofit Energy Use}

Pre- and post-retrofit energy use was compared for the 17 homes where utility data were secured.

\subsection{Site and Source Energy}

Energy data in the report are shown as both site and source energy. The site energy data come directly from the home's energy bills. The source energy data were calculated using multipliers for each of the types of energy used among the 17 homes with utility bill data. Source energy accounts for generation and transmission losses and is particularly impactful when looking at grid-generated electricity, which all 17 of the homes have. One home among the 17 (Manchester) is an all-electric house. Two homes have photovoltaic arrays that were not installed as part of the HPwES work. The homes are net metered and as such only the kilowatt-hours pulled from the grid were included in the site and source energy calculations.

Table 14. Source-Site Ratios for Commonly Used Fuels (US EPA, 2011)

\begin{tabular}{c|c|c}
\hline Fuel Type & Source-Site Ratio & $\begin{array}{c}\text { Number of Homes } \\
\text { Using This Fuel }\end{array}$ \\
\hline Electricity (Grid Purchase) & 3.34 & 17 \\
Natural Gas & 1.047 & 14 \\
\#2 Fuel Oil & 1.01 & 1 \\
Propane & 1.01 & 1 \\
\hline
\end{tabular}

\subsection{Utility Bill Data}

To compare pre- and post-HPwES retrofit energy use, a minimum of 2 years of utility data were needed for each home, 1 year prior to the HPwES retrofit and 1 year after the retrofit. Nine utility companies serve the homes in this study_Public Service Electric and Gas, Jersey Central Power and Light, Atlantic City Electric, Orange and Rockland Electric, New Jersey Natural Gas, South Jersey Gas, Elizabethtown Gas, Ferrel Gas, and Skylands Energy. Three of these utilities keep data for only 2 years. That impacted the data collection for 13 of the homes. For those homes, the utility bill information collected by the HPwES contractor was used as the pre-retrofit energy data. As such, at times there is a gap between the pre- and post-retrofit utility data or between the heating energy data and the kilowatt-hour data. Also, the data collection period for heating energy (natural gas, propane, or fuel oil) is often different than the data collection period for electricity for the same data availability reason. 
Table 15. Utility Bill Data and Time Periods for the 17 Houses $^{7}$

\begin{tabular}{|c|c|c|c|c|c|c|c|}
\hline $\begin{array}{c}\text { House } \\
\text { Location }\end{array}$ & $\begin{array}{l}\text { Pre- or } \\
\text { Post- } \\
\text { Retrofit }\end{array}$ & $\begin{array}{l}\text { Time Period } \\
\text { for Electricity }\end{array}$ & $\begin{array}{l}\text { Electricity } \\
(\mathrm{kWh})\end{array}$ & $\begin{array}{l}\text { Time Period for } \\
\text { Natural Gas, } \\
\text { Propane, or } \\
\text { Fuel Oil }\end{array}$ & $\begin{array}{l}\text { Natural Gas } \\
\text { (therms) } \\
\text { Propane, or } \\
\text { Fuel Oil } \\
\text { (gal) }^{8}\end{array}$ & $\begin{array}{l}\text { Total Site } \\
\text { Energy } \\
\text { (MMBtu) }\end{array}$ & $\begin{array}{c}\text { Total } \\
\text { Source } \\
\text { Energy } \\
\text { (MMBtu) }\end{array}$ \\
\hline Wharton & Pre & $12 / 09-11 / 10$ & 3,100 & $3 / 10-2 / 11$ & 608 & 83 & 128 \\
\hline Fanwood & $\begin{array}{l}\text { Pre } \\
\text { Post }\end{array}$ & $\begin{array}{l}5 / 10-4 / 11 \\
6 / 11-5 / 12\end{array}$ & $\begin{array}{l}3,285 \\
9,498 \\
8,370\end{array}$ & $\begin{array}{l}4 / 11-3 / 12 \\
2 / 10-1 / 11 \\
9 / 11-8 / 12\end{array}$ & $\begin{array}{l}404 \\
894 \\
604\end{array}$ & $\begin{array}{l}04 \\
147 \\
102\end{array}$ & $\begin{array}{l}99 \\
281 \\
171\end{array}$ \\
\hline Delran & $\begin{array}{l}\text { Pre } \\
\text { Post }\end{array}$ & $\begin{array}{l}2 / 10-1 / 11 \\
4 / 11-3 / 12\end{array}$ & $\begin{array}{l}6,765 \\
6,199\end{array}$ & $\begin{array}{l}2 / 10-1 / 11 \\
4 / 11-3 / 12\end{array}$ & $\begin{array}{l}940 \\
633\end{array}$ & $\begin{array}{c}136 \\
99\end{array}$ & $\begin{array}{l}233 \\
152\end{array}$ \\
\hline Freehold & $\begin{array}{l}\text { Pre } \\
\text { Post }\end{array}$ & $\begin{array}{l}9 / 09-8 / 10 \\
9 / 11-8 / 12\end{array}$ & $\begin{array}{l}9,850 \\
7,612\end{array}$ & $\begin{array}{l}1 / 10-12 / 10 \\
1 / 11-12 / 11\end{array}$ & $\begin{array}{l}763 \\
664\end{array}$ & $\begin{array}{l}133 \\
108\end{array}$ & $\begin{array}{l}260 \\
196\end{array}$ \\
\hline Edison & $\begin{array}{l}\text { Pre } \\
\text { Post }\end{array}$ & $\begin{array}{l}4 / 10-3 / 11 \\
4 / 11-3 / 12\end{array}$ & $\begin{array}{l}12,191 \\
10,647\end{array}$ & $\begin{array}{l}3 / 10-2 / 11 \\
5 / 11-4 / 12\end{array}$ & $\begin{array}{l}557 \text { (f.o.) } \\
305 \text { (f.o.) }\end{array}$ & $\begin{array}{c}101 \\
56\end{array}$ & $\begin{array}{c}205 \\
97\end{array}$ \\
\hline Mahwah & $\begin{array}{l}\text { Pre } \\
\text { Post }\end{array}$ & $\begin{array}{c}1 / 10-12 / 10 \\
1 / 11-1 / 12\end{array}$ & $\begin{array}{l}9,050 \\
7,729\end{array}$ & $\begin{array}{l}1 / 10-12 / 10 \\
2 / 11-1 / 12\end{array}$ & $\begin{array}{l}477 \\
339\end{array}$ & $\begin{array}{l}78 \\
46\end{array}$ & $\begin{array}{c}169 \\
77\end{array}$ \\
\hline Toms River & $\begin{array}{l}\text { Pre } \\
\text { Post }\end{array}$ & $\begin{array}{l}3 / 10-2 / 11 \\
3 / 12-2 / 13\end{array}$ & $\begin{array}{l}4,970 \\
4,618\end{array}$ & $\begin{array}{l}5 / 10-4 / 11 \\
6 / 11-5 / 12\end{array}$ & $\begin{array}{c}1187 \\
670\end{array}$ & $\begin{array}{c}114 \\
79\end{array}$ & $\begin{array}{c}120 \\
83\end{array}$ \\
\hline Woodbury & $\begin{array}{l}\text { Pre } \\
\text { Post }\end{array}$ & $\begin{array}{l}3 / 10-2 / 11 \\
3 / 11-2 / 12\end{array}$ & $\begin{array}{c}10,844 \\
6,831\end{array}$ & $\begin{array}{l}3 / 10-2 / 11 \\
3 / 11-2 / 12\end{array}$ & $\begin{array}{l}872 \\
505\end{array}$ & $\begin{array}{c}130 \\
69\end{array}$ & $\begin{array}{l}247 \\
101\end{array}$ \\
\hline Boonton & $\begin{array}{l}\text { Pre } \\
\text { Post }\end{array}$ & $\begin{array}{l}1 / 10-12 / 10 \\
10 / 11-9 / 12\end{array}$ & $\begin{array}{l}9,877 \\
5,257\end{array}$ & $\begin{array}{l}2 / 10-1 / 12 \\
2 / 11-1 / 12\end{array}$ & $\begin{array}{c}1164 \\
715\end{array}$ & $\begin{array}{c}162 \\
93\end{array}$ & $\begin{array}{l}281 \\
141\end{array}$ \\
\hline Sewell & $\begin{array}{l}\text { Pre } \\
\text { Post }\end{array}$ & $\begin{array}{l}11 / 9-10 / 10 \\
10 / 11-9 / 12\end{array}$ & $\begin{array}{l}8,420 \\
6,134\end{array}$ & $\begin{array}{l}3 / 10-2 / 11 \\
3 / 11-2 / 12\end{array}$ & $\begin{array}{l}705 \\
506\end{array}$ & $\begin{array}{c}124 \\
82\end{array}$ & $\begin{array}{l}247 \\
137\end{array}$ \\
\hline Skillman & $\begin{array}{l}\text { Pre } \\
\text { Post }\end{array}$ & $\begin{array}{l}6 / 10-5 / 11 \\
6 / 11-5 / 12\end{array}$ & $\begin{array}{l}3,248 \\
5,018\end{array}$ & $\begin{array}{l}6 / 10-5 / 11 \\
7 / 11-6 / 12\end{array}$ & $\begin{array}{l}834 \\
384\end{array}$ & $\begin{array}{c}103 \\
64\end{array}$ & $\begin{array}{l}152 \\
106\end{array}$ \\
\hline Springfield & $\begin{array}{l}\text { Pre } \\
\text { Post }\end{array}$ & $\begin{array}{c}2 / 10-1 / 11 \\
10 / 11-9 / 12\end{array}$ & $\begin{array}{l}14,464 \\
10,228\end{array}$ & $\begin{array}{l}5 / 10-4 / 11 \\
6 / 11-5 / 12\end{array}$ & $\begin{array}{l}554 \\
444\end{array}$ & $\begin{array}{c}138 \\
92\end{array}$ & $\begin{array}{l}326 \\
181\end{array}$ \\
\hline
\end{tabular}

\footnotetext{
${ }^{7}$ These are actual utility bill data and are not weather normalized, as such there are not columns showing the pre- and post-energy use percentage differences.

${ }^{8}$ Unless otherwise noted this column shows therms of natural gas.
} 


\begin{tabular}{c|c|c|c|c|c|c|c}
\hline $\begin{array}{c}\text { House } \\
\text { Location }\end{array}$ & $\begin{array}{c}\text { Pre- or } \\
\text { Post- } \\
\text { Retrofit }\end{array}$ & $\begin{array}{c}\text { Time Period } \\
\text { for Electricity }\end{array}$ & $\begin{array}{c}\text { Electricity } \\
\text { (kWh) }\end{array}$ & $\begin{array}{c}\text { Time Period for } \\
\text { Natural Gas, } \\
\text { Propane, or } \\
\text { Fuel Oil }\end{array}$ & $\begin{array}{c}\text { Natural Gas } \\
\text { (therms) } \\
\text { Propane, or } \\
\text { Fuel Oil } \\
\text { (gal) }\end{array}$ & $\begin{array}{c}\text { 8otal Site } \\
\text { Energy } \\
\text { (MMBtu) }\end{array}$ & $\begin{array}{c}\text { Total } \\
\text { Source } \\
\text { Energy } \\
\text { (MMBtu) }\end{array}$ \\
\hline \multirow{2}{*}{ Brick } & Pre & $1 / 10-12 / 10$ & 7,125 & $1 / 10-12 / 10$ & 753 & 119 & 215 \\
& Post & $10 / 11-9 / 12$ & 6,343 & $1 / 11-12 / 11$ & 500 & 77 & 134 \\
Augusta & Pre & $2 / 10-1 / 11$ & 13,717 & $5 / 10-4 / 11$ & 1255 (pro.) & 200 & 375 \\
& Post & $10 / 11-9 / 12$ & 13,169 & $5 / 11-4 / 12$ & 781 (pro.) & 145 & 259 \\
Sicklerville & Pre & $3 / 10-2 / 11$ & 6,480 & $4 / 10-3 / 11$ & 666 & 107 & 203 \\
& Post & $10 / 11-9 / 12$ & 5,947 & $4 / 11-3 / 12$ & 373 & 68 & 121 \\
\hline \multirow{2}{*}{ Glassboro } & Pre & $10 / 09-9 / 10$ & 7,745 & $2 / 10-1 / 11$ & 744 & 127 & 248 \\
& Post & $12 / 11-11 / 12$ & 6,965 & $3 / 11-2 / 12$ & 485 & 82 & 145 \\
\hline \multirow{2}{*}{ Manchester } & Pre & $8 / 09-7 / 10$ & 18,010 & N/A & N/A & 137 & 457 \\
& Post & $10 / 11-9 / 12$ & 12,252 & N/A & N/A & 96 & 322 \\
\hline
\end{tabular}




\subsection{Weather Normalization of Utility Data}

The raw utility data were normalized by charting monthly therms alongside monthly heating degree days (HDDs) and kilowatt-hours alongside monthly cooling degree days (CDDs). When heating energy was provided in gallons of propane or \#2 fuel oil, it was converted to therms. Months without any HDDs (typically June, July, and August) were used to calculate the average monthly therm base load. Once the annual base load was calculated (using the actual therm amounts from the summer months and adding the average monthly amount for the remaining 9 months), the therms per HDD were calculated. ${ }^{9}$ This was done by adding the therms for all the months with degree days (typically September through May), subtracting the base load for those months and dividing that total by the total HDDs. These calculations were done for both the preretrofit and post-retrofit data. These results were then applied to Typical Meteorological Year 3 data.

On the electricity side, there was not always a clear relationship between CDDs and kilowatthours used. As a preliminary check, the average kilowatt-hours for months with no CDDs (typically October through April) were compared to the average kilowatt-hours during months with CDDs (typically May through September). If the averages were close, there was not a definite AC load impact, or at least not one great enough to offset the increased lighting load during the shorter winter months. If no relationship was found, kilowatt-hours per CDD based on annual totals were calculated. If the CDD kilowatt-hour average was clearly higher than the nonCDD kilowatt-hour average, a base load was calculated and subtracted from the total use. This sum was then divided by CDDs to find kilowatt-hours per CDD. The calculated base load was then added to the kilowatt-hour per CDD times the TMY3 CDDs.

The following figures show:

- Pre- and post-retrofit source energy use (Figure 8)

- Post-retrofit source energy percentage savings (Figure 9)

- Pre- and post-retrofit source energy use intensity (EUI) (Figure 10)

- Pre-retrofit source energy use and percentage savings (Figure 11)

- Conditioned floor area and post-retrofit source EUI (Figure 12)

- Retrofit cost and percentage source energy savings (Figure 13)

- Pre- and post-retrofit ACH50 (Figure 14)

- Estimated and actual savings for 17 Tier 3 Level 2 homes (Figure 15).

\footnotetext{
${ }^{9}$ This method may be underestimating the base load, since the DHW load is likely higher in the winter due to lower ground water temperatures.
} 


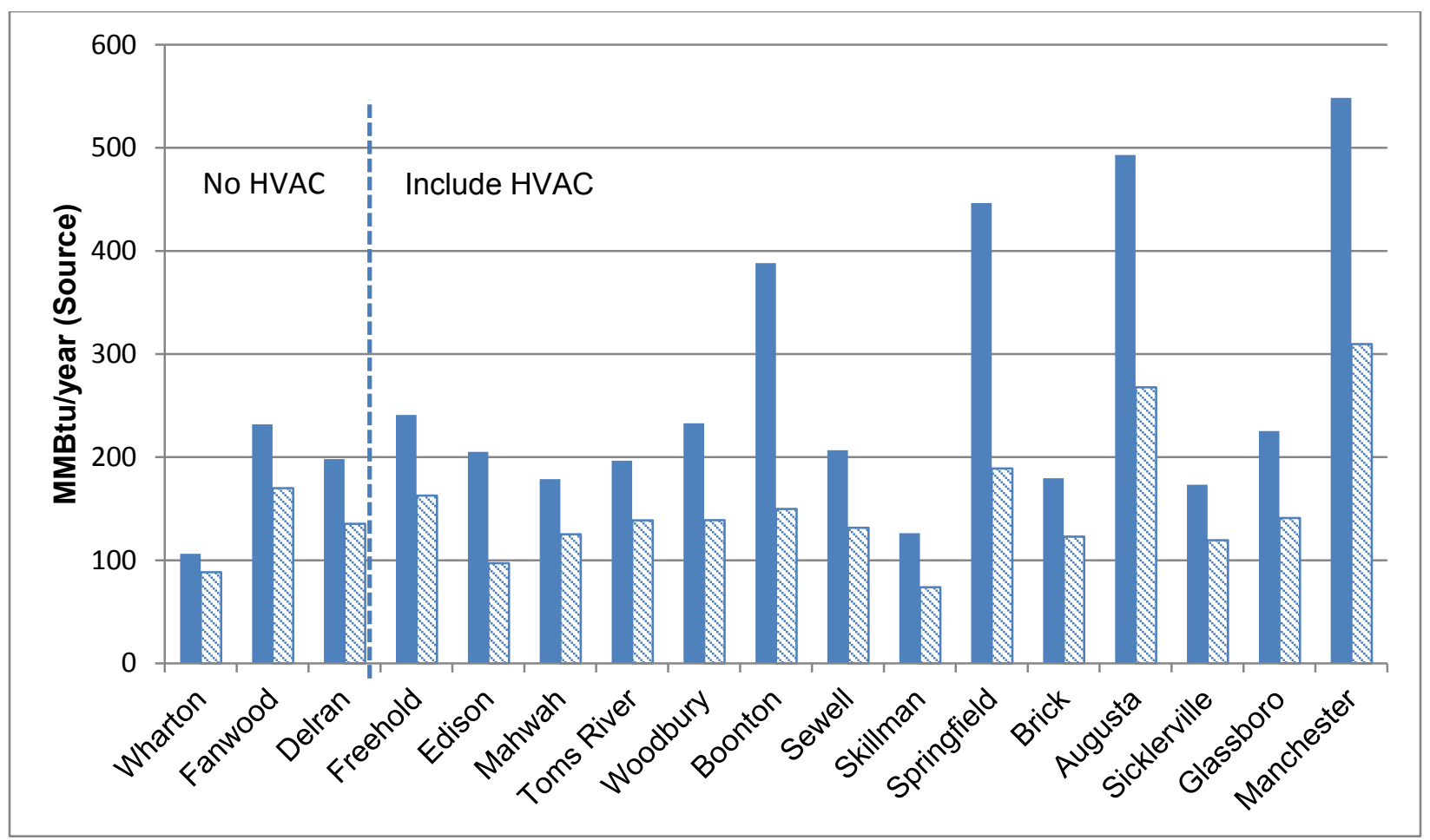

Figure 8. Pre- and post-retrofit source energy use

Figure 8 shows the pre- and post-retrofit source energy use among the 17 New Jersey HPwES homes for which utility data were collected. The reductions in MMBtu/year range from a low of $18 \mathrm{MMBtu} /$ year (Wharton) to a high of $257 \mathrm{MMBtu} /$ year (Springfield). 


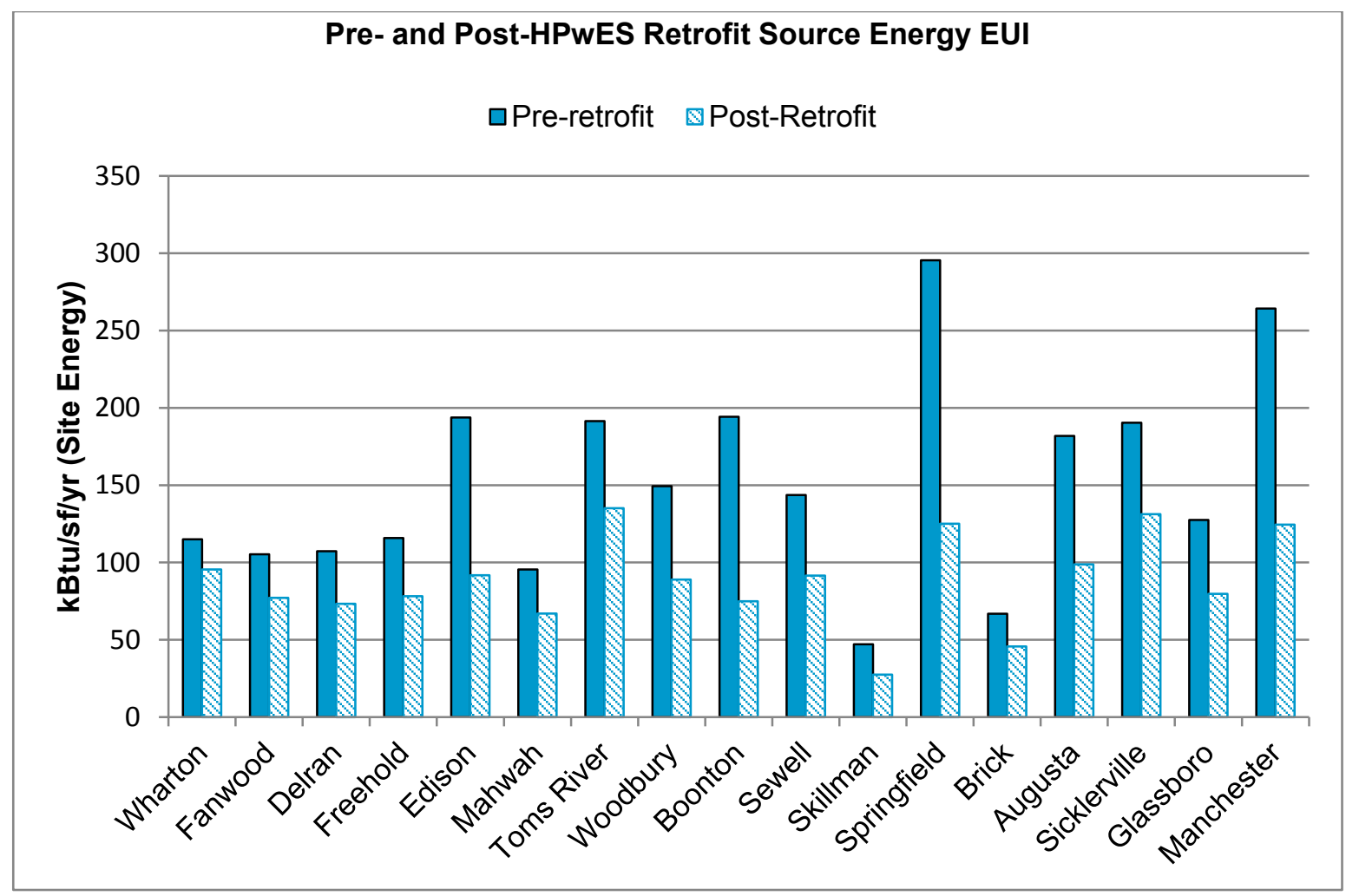

Figure 9. Pre- and post-retrofit source EUI

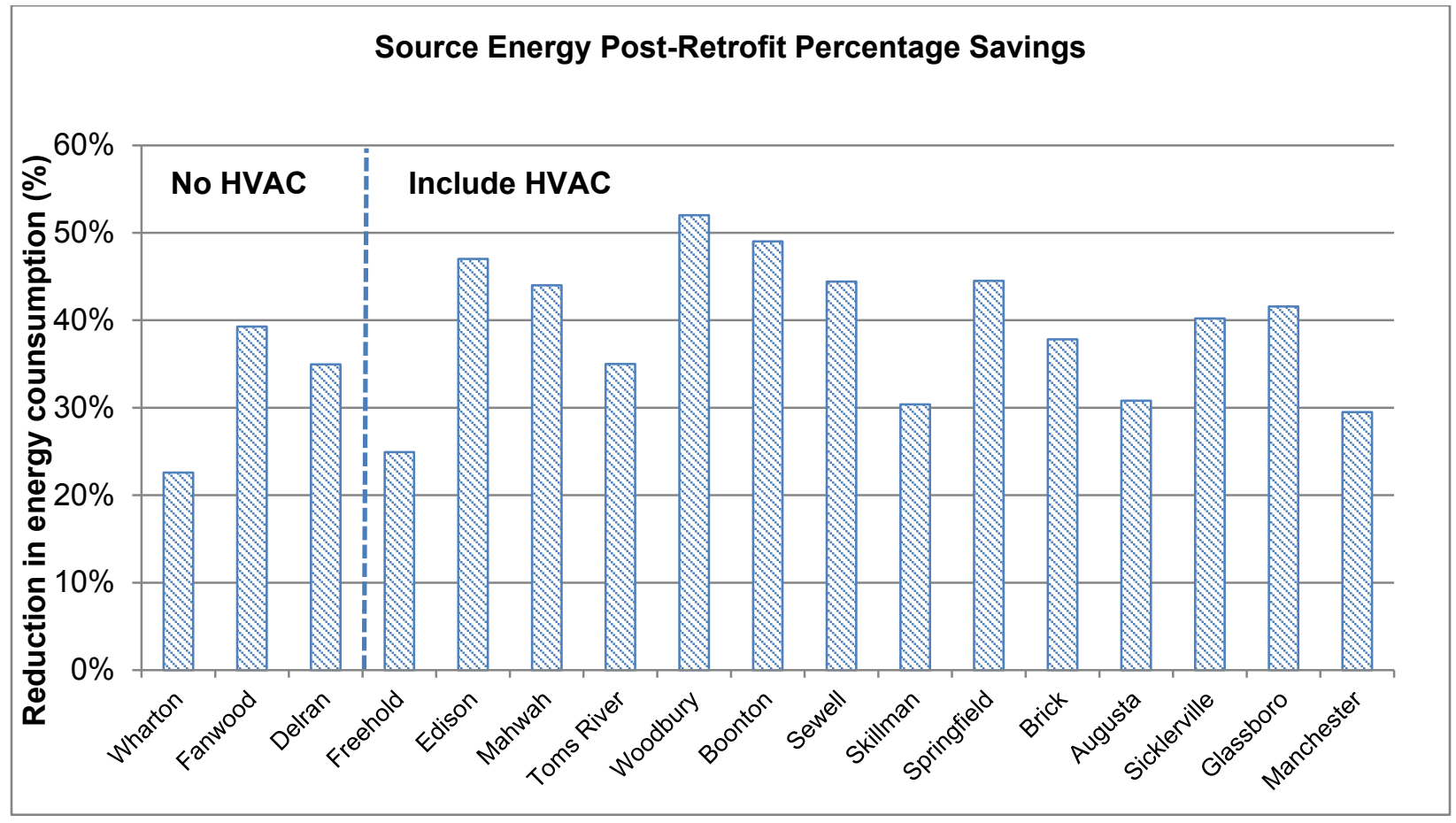

Figure 10. Post-retrofit source energy percentage savings 
The average source energy use percentage reduction was $38.03 \%$.

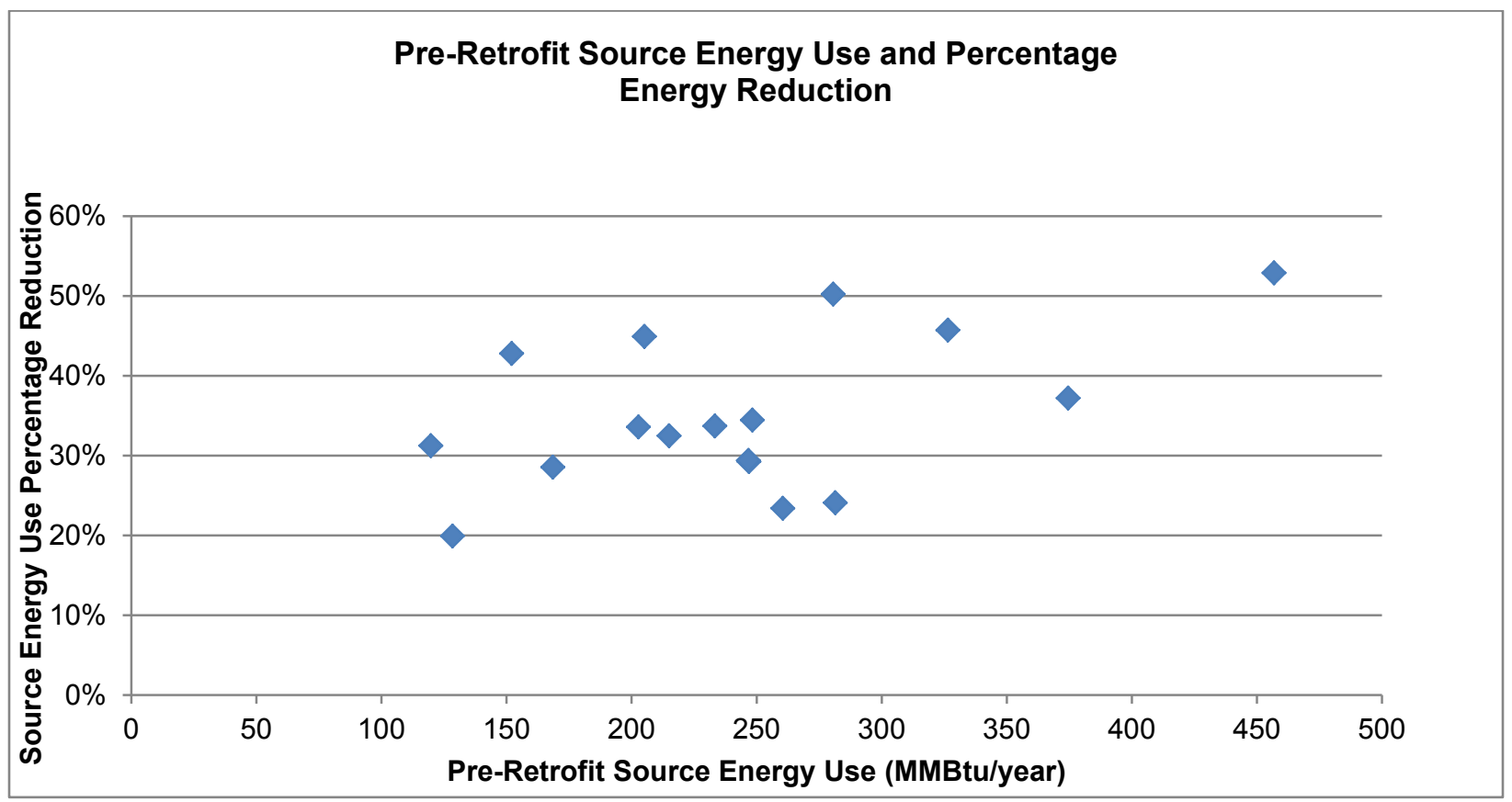

Figure 11. Pre-retrofit source energy use and percentage savings

There is a statistically significant relationship between the pre-retrofit source energy use and the post-retrofit energy use reduction, using a $95 \%$ interval. It is interesting to note that the highest pre-retrofit energy use of $457 \mathrm{MMBtu} / \mathrm{year}$ also had the highest source energy use reduction at $53 \%$. This is also the only all-electric house in the study (Manchester). This house switched from electric resistance heating to an HSPF 9, SEER 15.5 air source heat pump. 


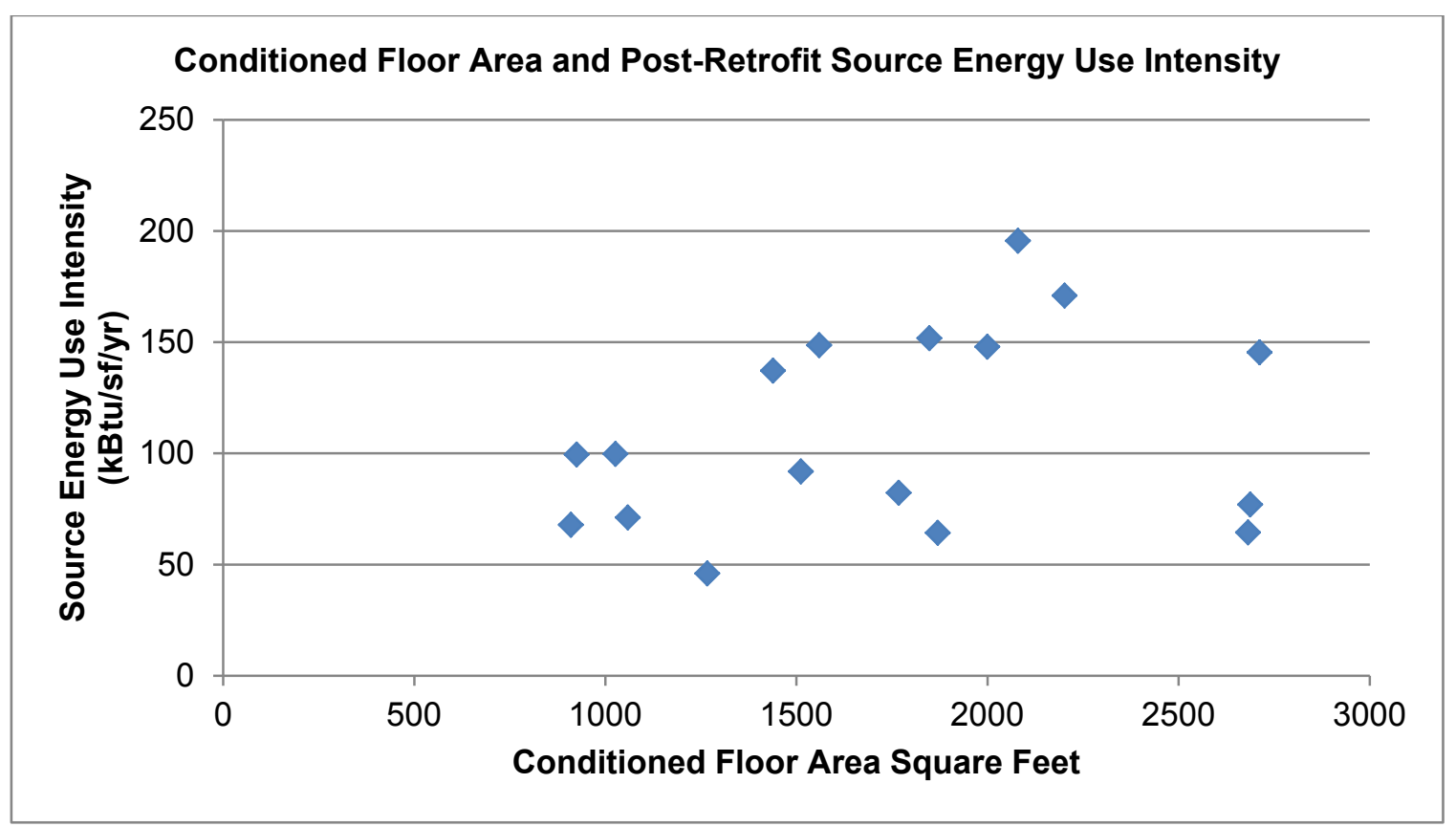

Figure 12. Conditioned floor area and post-retrofit source EUI

There is no statistically significant relationship between the conditioned floor area and the postretrofit source EUI among the 17 homes.

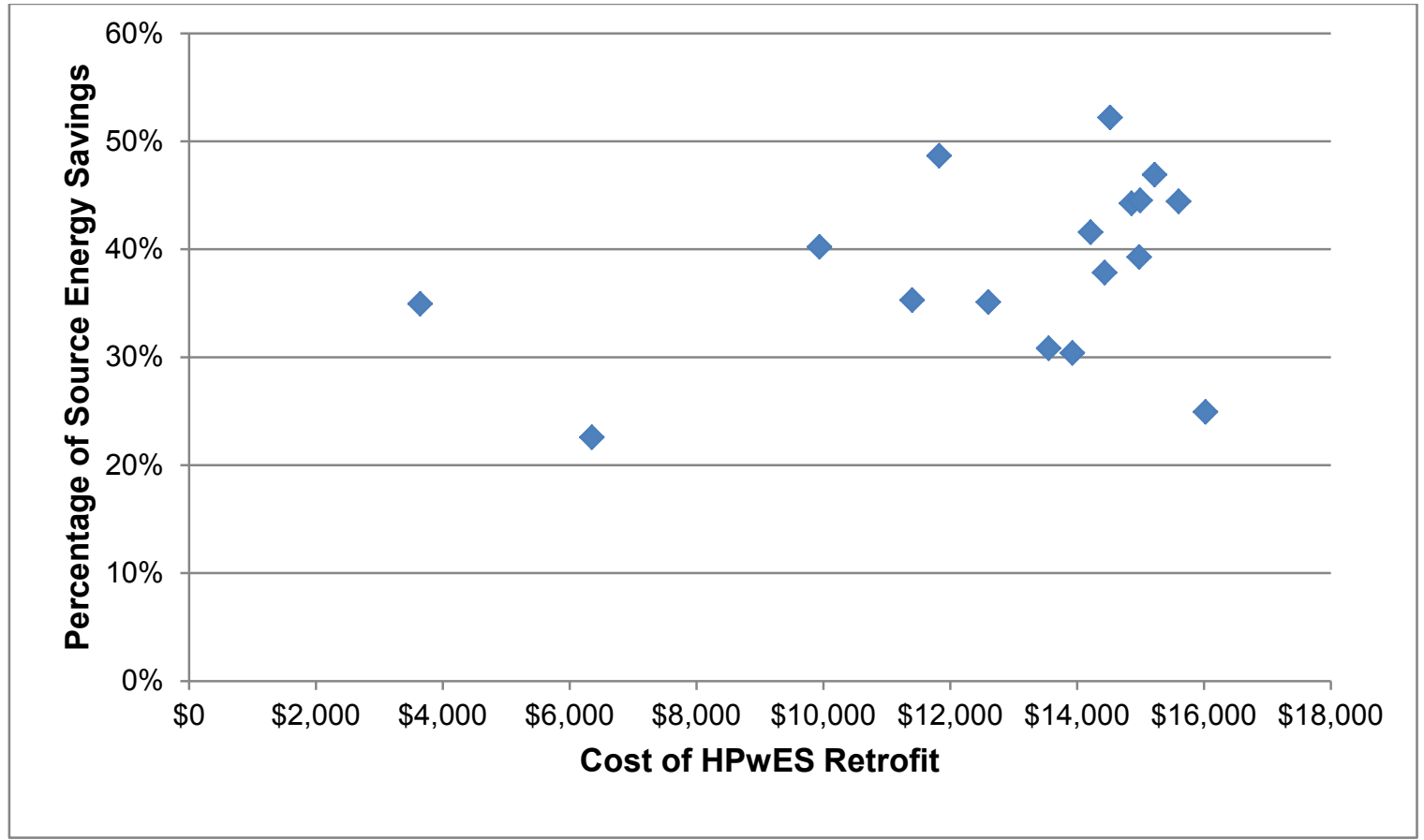

Figure 13. Retrofit cost and percentage source energy savings 
There is a statistically significant relationship between cost of the renovation and percentage of energy savings, but only when the outlier of Freehold ( $\$ 16,024,25 \%$ savings) is removed. A more aggressive approach to air sealing may diminish the cost/energy savings relationship in future retrofits.

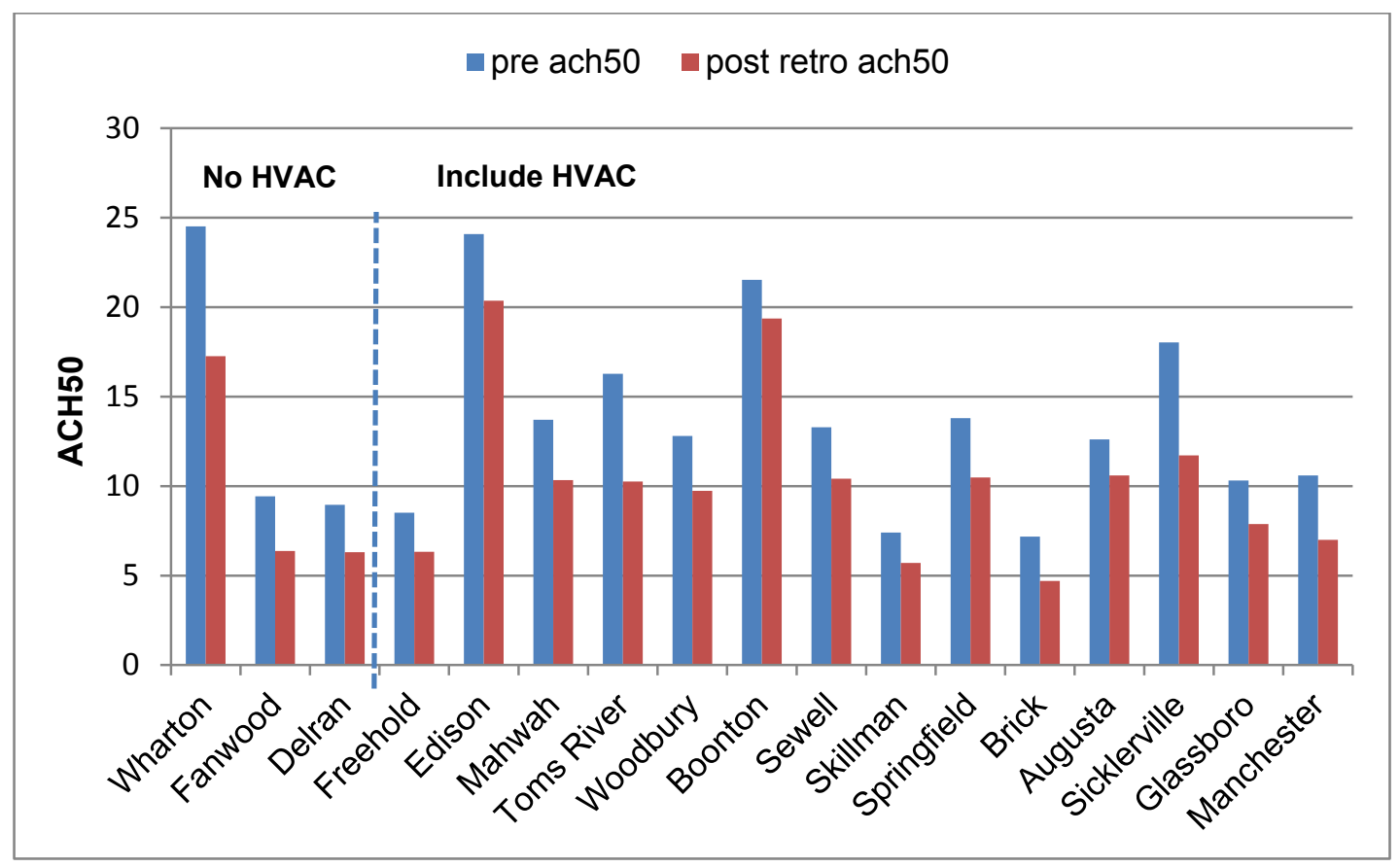

Figure 14. Pre- and post-retrofit ACH50

Three homes stand out as having very high post-retrofit ACH50: Wharton, Edison, and Boonton. Six more have post-retrofit ACH50 ratings about 10, further showing that more can be done with infiltration reduction in most of these homes. 


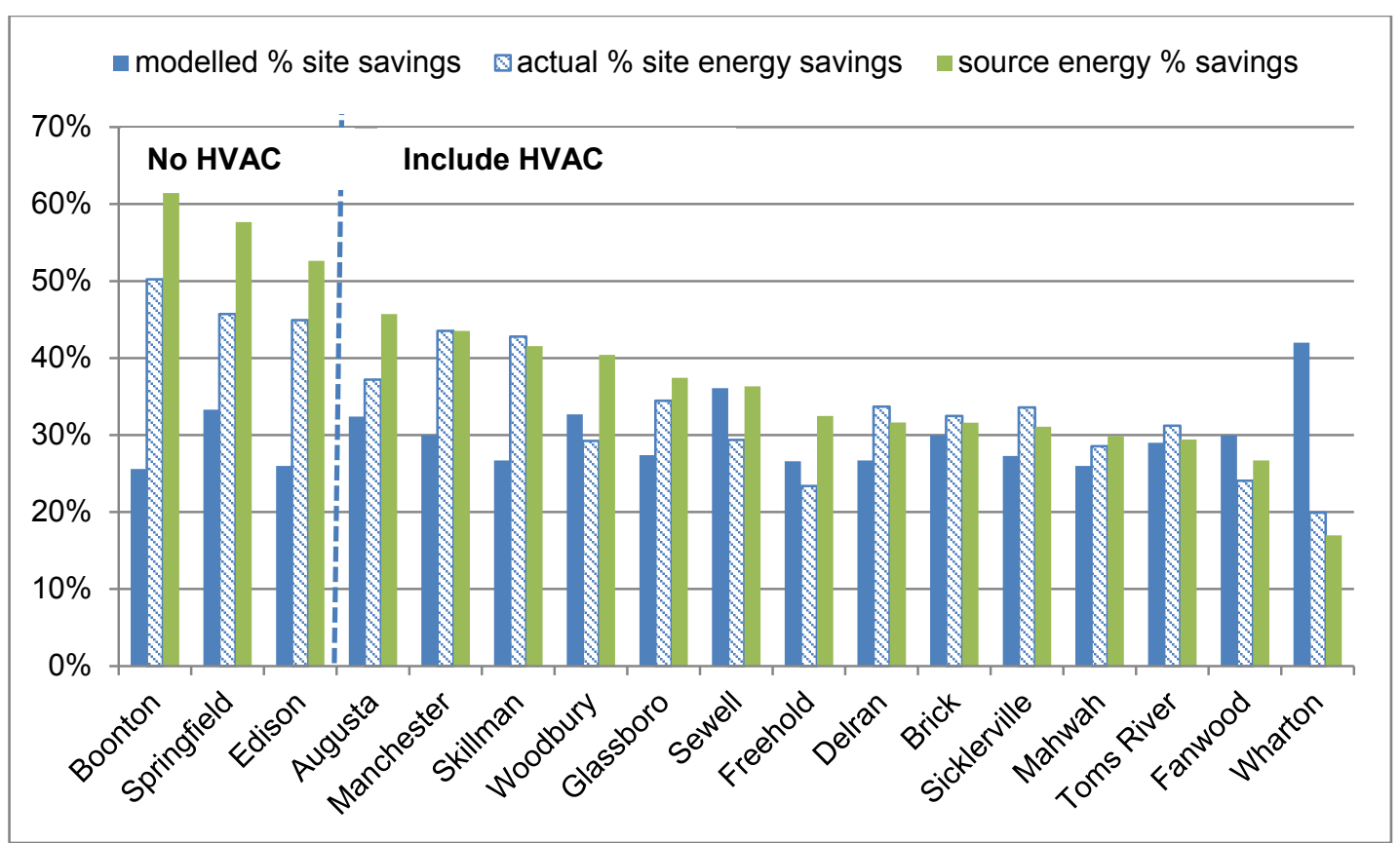

Figure 15. Estimated and actual savings for 17 Tier 3 Level 2 homes

Five of the 17 homes with utility data had lower actual savings than predicted, while 12 had higher savings. Savings exceeding predictions outweighed shortfalls, resulting in the average predicted savings of $29.87 \%$, the average actual site energy savings of $34.7 \%$, and the average source energy savings of $38.03 \%$. 


\section{Conclusion}

BARA's research in this project has concluded that the New Jersey HPwES program is achieving source energy savings in existing homes that meet or exceed BA's goal of 30\%, and some of these packages are doing so without the costly replacement of heating and cooling equipment, which indicates that less costly envelope packages could be offered to consumers unable to invest in more costly mechanical packages, potentially creating broader market impact. The packages of measures used in the New Jersey HPwES program, both those with and without HVAC equipment replacement, can be included as part of the BA retrofit checklist for climate zones 4 and 5. Pairing the findings from this research with existing BA guidance documents, such as the Building America Best Practices Series, Energy Renovations, HVAC, (Pacific Northwest National Laboratory \& Oak Ridge National Laboratory, 2011)can help guide retrofit packages that tailor their approach toward more robust envelope improvements before mechanical equipment is replaced, resulting in relatively low-cost, high-impact energy improvement packages.

Additional research efforts are necessary to address other climate zones by evaluating HPwES project results and developing ideal packages for those climate zones. Additional research efforts should focus on evaluating enclosure packages and the recommendation of these packages by HPwES contractors to evaluate if there is potential for HPwES to have a greater market impact by providing less costly options for consumers unable to invest in equipment replacement. Findings from this research, and subsequent research efforts, could serve to be the basis of BA's "proven performance packages" for existing homes, and could be implemented through the HPwES program, thus achieving programmatic goals of providing research and guidance for radically improving our nation's existing housing stock.

The research questions and subsequent answers revealed by this research are as follows:

1. What was the average and individual difference between the projected post-retrofit energy use and the actual post-retrofit energy use?

Five of the 17 homes with utility data had lower actual savings than predicted, while 12 had higher savings. Savings exceeding predictions outweighed shortfalls, resulting in the average of predicted savings of $29.87 \%$, the average of actual site energy savings of $34.7 \%$, and the average of source energy savings of $38.03 \%$ (see Table 16 and Figure 16). 
Table 16. Comparison of Modeled Site and Actual Percentage Savings

\begin{tabular}{|c|c|c|c}
\hline Wharton & $\begin{array}{c}\text { Modeled Site } \\
\text { Energy \% } \\
\text { Savings }\end{array}$ & $\begin{array}{c}\text { Site Energy \% } \\
\text { Savings }\end{array}$ & $\begin{array}{c}\text { Source Energy } \\
\% \text { Savings }\end{array}$ \\
\hline Fanwood & $42 \%$ & $20 \%$ & $17 \%$ \\
\hline Delran & $30 \%$ & $24 \%$ & $27 \%$ \\
\hline Freehold & $27 \%$ & $34 \%$ & $32 \%$ \\
\hline Edison & $27 \%$ & $23 \%$ & $32 \%$ \\
\hline Mahwah & $26 \%$ & $45 \%$ & $53 \%$ \\
\hline Toms River & $29 \%$ & $29 \%$ & $30 \%$ \\
\hline Woodbury & $33 \%$ & $31 \%$ & $29 \%$ \\
\hline Boonton & $26 \%$ & $29 \%$ & $40 \%$ \\
\hline Sewell & $36 \%$ & $50 \%$ & $61 \%$ \\
\hline Skillman & $20 \%$ & $43 \%$ & $36 \%$ \\
\hline Springfield & $33 \%$ & $46 \%$ & $42 \%$ \\
\hline Brick & $30 \%$ & $32 \%$ & $58 \%$ \\
\hline Augusta & $32 \%$ & $37 \%$ & $32 \%$ \\
\hline Sicklerville & $27 \%$ & $34 \%$ & $46 \%$ \\
\hline Glassboro & $27 \%$ & $34 \%$ & $31 \%$ \\
\hline Manchester & $30 \%$ & $44 \%$ & $37 \%$ \\
\hline AVERAGE & $30 \%$ & $34 \%$ & $44 \%$ \\
\hline
\end{tabular}

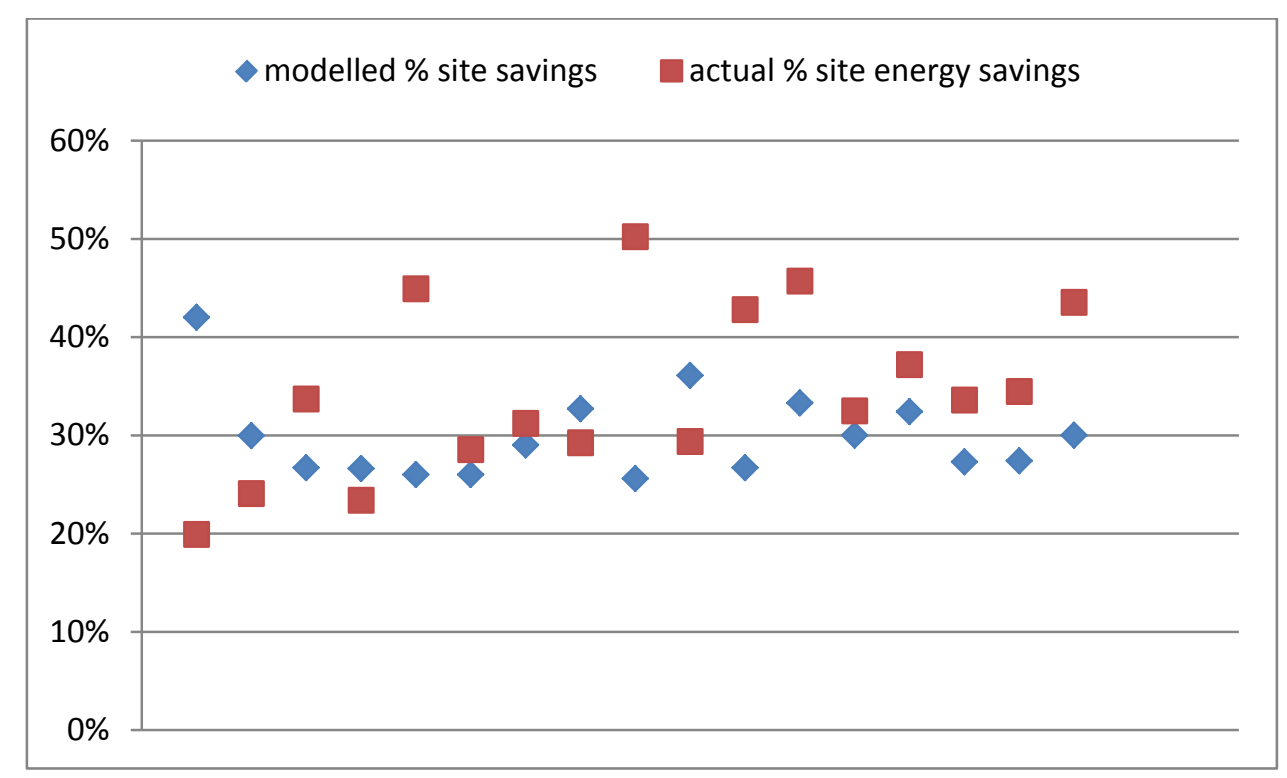

Figure 16. Modeled and actual \% site energy savings 
As shown in Figure 16, the actual site savings typically exceed the modeled savings. Figure 17 shows the envelope package areas of focus.



Figure 17. Envelope package areas of focus

2. What packages of measures were implemented in projects that had an actual energy use reduction of the $30 \%$ range?

Packages of measures varied, but the overall distinction is packages where heating and or cooling equipment was replaced or installed versus packages where this type of equipment was not installed. The packages with mechanical equipment had higher levels of savings that those without mechanical equipment $(36 \%$ versus $26 \%)$, but also had higher costs $(\$ 13,793$ versus $\$ 8,325)$. This suggests that both types of packages can meet the BA goals.

3. What prescriptive package, based on the results of question 2, might predictably deliver an energy savings reduction of $30 \%$ or more?

Example packages of both types are shown in Table 17.

The air sealing measure is shown with the criteria of tightening the home within 200 CFM50 of the BAS or beyond and providing mechanical ventilation (see Figure 18). As noted earlier, among the 42 tier 3 level 2 New Jersey HPwES homes within this research, the average infiltration reduction was 715 CFM50 over their BAS. As such, more thorough, complete air sealing could make the envelope package even more robust. 
Table 17. Proposed Prescriptive Packages To Achieve 30\% Savings in Climate Zones 4 and 5

\begin{tabular}{c|c|c}
\hline Envelope Package & Measure & HVAC Package \\
\hline X & $\begin{array}{c}\text { Air Sealing to within 200 CFM50 of BAS as } \\
\text { attainable } \\
\text { or }\end{array}$ & X \\
& $\begin{array}{c}\text { Air sealing beyond the BAS and provide } \\
\text { mechanical ventilation }\end{array}$ \\
X & Attic hatch insulation to R-19 \\
X & Attic floor insulation to R-38 & X \\
X & Above grade wall insulation to R-13 & X \\
X & Basement wall insulation to R-10 & \\
& Replace heating equipment & X \\
& Replace (or install) cooling equipment & X \\
& Replace water heater & X \\
\hline
\end{tabular}

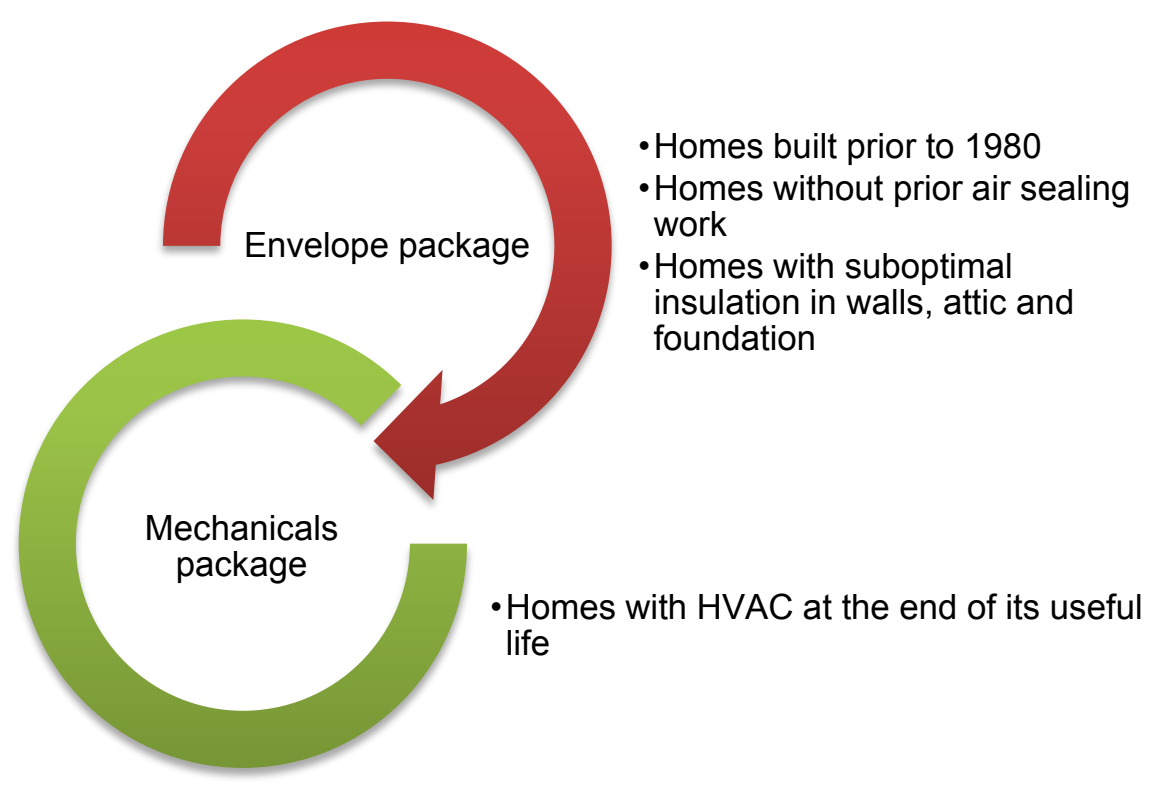

Figure 18. Existing conditions suited to envelope package and mechanicals package

4. What existing conditions, such as the existing infiltration rate, existing insulation levels, and/or efficiency of the mechanical system, would make a home a good candidate for the prescriptive package?

The envelope package would be most effective in homes without prior air sealing work and homes with low levels of insulation in the walls, attic and at the rim joist (as accessible), and basement. As such, homes built prior to 1980 that have not had previous energy work are good candidates. Homes of this age typically have suboptimal insulation levels. Older homes are also leakier than new homes, as shown by a study from the Florida Solar Energy Center (Figure 19). Granted, this is based on Florida homes, not New Jersey. Other studies have found that, generally, existing U.S. homes are very leaky and can be tightened $25 \%$ and still not be too tight (Sherman M. , 2010). 


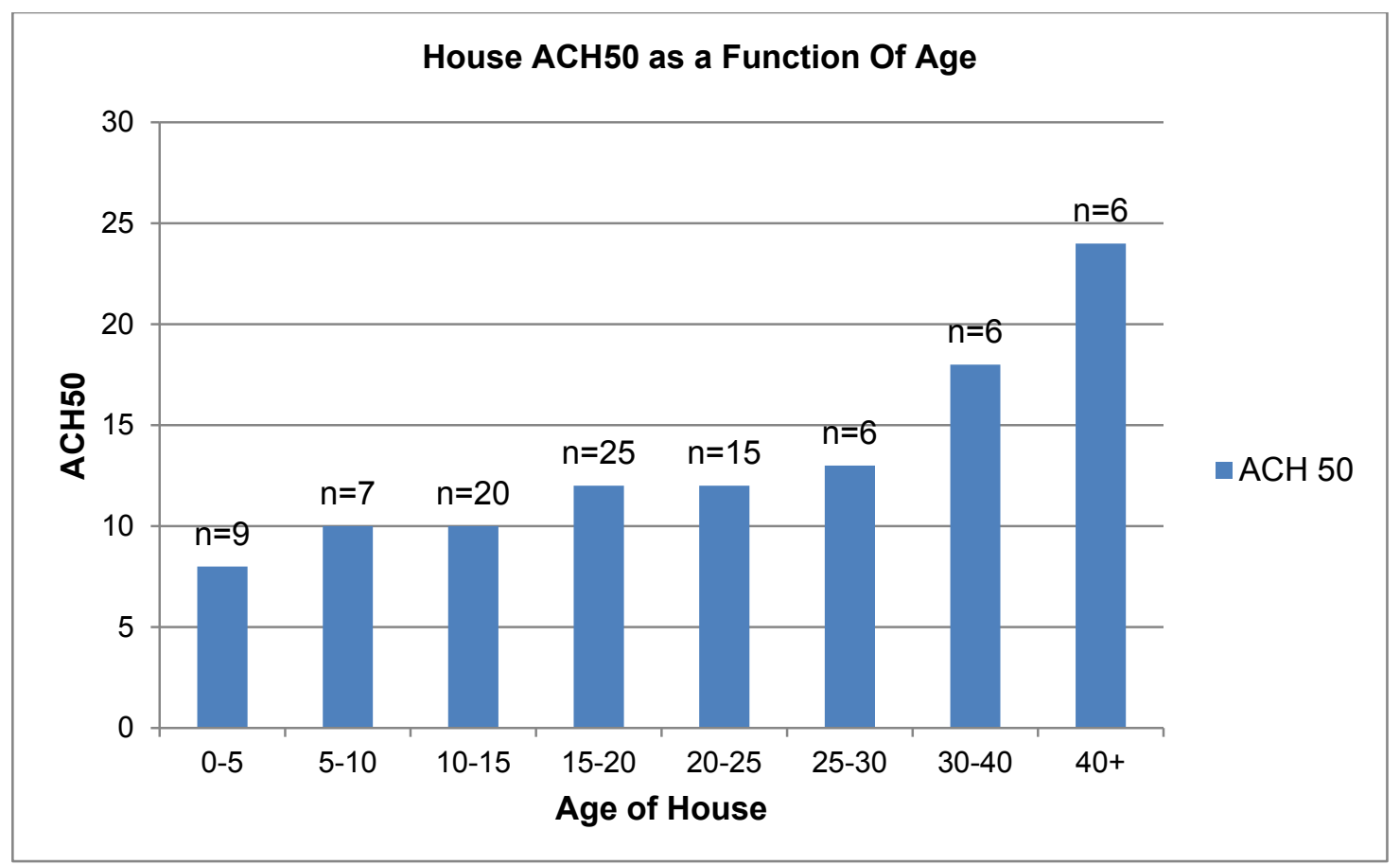

Figure 19. House $\mathrm{ACH}$ as a function of age (Cummings, Tooley, \& Moyer, 1991)

For homes with mechanical equipment that needs to be replaced for reasons other than energy efficiency, heating and/or cooling could be added to a comprehensive envelope improvement package, allowing lower capacity equipment to be installed. Most equipment lasts for about 20 years and homes from the 1990s and older, that have not replaced their mechanical equipment, would most likely be good candidates for the envelope plus HVAC package. 


\section{References}

Belzer, D. M. (2007). Home Performance with ENERGY STAR: Utility Bill Analysis on Homes Participating in Austin Energy's Program. Golden: NREL.

BPI. (2005, Febuary 28). Technical Standards for the Building Analyst Professional. Malta, NY, USA: BPI.

CSG. (2012). New Jersey Home Performance with Energy Star Real Home Analyzer Software Users Manual. Iselin: Conservation Services Group.

Cummings, J., Tooley, J., \& Moyer, N. (1991, January 31). Investigation of Air Distribution System Leakage and Its Impacts in Central Florida Homes. Retrieved November 20, 2013, from Florida Solar Energy Center: http://www.fsec.ucf.edu/en/publications/html/FSEC-CR-397-91/

DOE. (2014, March 11). New Jersey's Clean Energy Program Energy Efficiency Committee Meeting. Trenton, NJ, USA.

EIA. (2009). Residential Energy Consumption Survey (RECS). Retrieved October 17, 2013, from U.S. Energy Information Administration:

http://www.eia.gov/consumption/residential/data/2009/index.cfm?view=consumption\#summary

EIA. (2012, December 14). 2009 RECS Survey Data. Retrieved October 17, 2013, from US Energy Information Administration:

http://www.eia.gov/consumption/residential/data/2009/index.cfm?view=consumption

Eisenberg, L. S. (2011). Retrofit NYC: Block by Block. Oak Ridge: U.S. DOE.

Energy Trust of Oregon. (2009). Energy Performance Score 2008 Pilot. Portland: Energy Trust of Oregon.

Enterprise Community Partners. (2012). Green Operations and Maintenance. Retrieved February 5, 2013, from Enterprise: http:/www.enterprisecommunity.com/solutions-andinnovation/enterprise-green-communities/resources/operations-and-maintenance-toolkit

Home Performance Resource Center. (2010). Case Study: New Jeresy Home Performance with Energy Star. Washington, DC: Home Performance Resource Center.

Homeowner's Rehab and Winn Development. (2011, June 2). Enterprise Green Communities. Retrieved February 5, 2013, from Enterprise: http://www.enterprisecommunity.com/searchresults?oSearch $=$ green + unit + turnover

Krigger, J., \& Dorsi, C. (2009). Residential Energy. Helena: Saturn Resource Management.

Liaukus, C. (2011). Best Practice: Commercially Viable Energy Efficient Solution Package Report. Wilmington: U.S. DOE. 
Liaukus, C. (2014, March 19). Home Performance with Energy Star, Which Measures Get you $30 \%$ Savings. Newark, NJ, USA.

Metzger, C. (2014, March 12). Clarification of Building America energy savings goals. (C. Liaukus, Interviewer)

NJ Office of Clean Energy. (2012, January 1). Eligible Measures. Retrieved October 17, 2013, from NJ Clean Energy Program:

http://www.njcleanenergy.com/files/file/Residential\%20Programs/HP/2012NJHPwESEligibleM easures122811.pdf

NJ Office of Clean Energy. (2013). Benefits and Incentives. Retrieved October 17, 2013, from New Jersey's Clean Energy Program: http://www.njcleanenergy.com/residential/programs/homeperformance-energy-star/benefits-and-incentives

NJ Office of Clean Energy. (2013). What to Expect from a Home Energy Audit. Retrieved October 17, 2013, from New Jersey's Clean Energy Program:

http://www.njcleanenergy.com/residential/programs/home-performance-energy-star/whatexpect-home-energy-assessment

NJCEP. (2010). Contractors. Retrieved March 28, 2014, from New Jersey Clean Energy Program: http://www.njcleanenergy.com/residential/programs/home-performance-energystar/contractors/contractors

Osser, R. N. (2012). Proven Performance of Seven Cold Climate Deep Retrofit Homes. Somerville: Building Science Corporation.

Raleigh Housing Authority. (2012, September 24). About Us. Retrieved November 12, 2010, from Raleigh Housing Authority: http://www.rhaonline.com/about.htm

Roberts, S., \& Stephenson, R. (2010). Guidlines for Measures and Strategies - Wall Air Sealing \& Insulation Methods in Existing Homes. Oak Ridge: US Department of Energy.

seattle.gov. (2011). Green Unit Turn. Retrieved February 5, 2013, from Office of Housing: http://www.seattle.gov/housing/greenunitturn/default.htm

Sherman, M. (2010). Air Tightness: Experience from the US. (p. 4). Berkeley: Lawrence Berkeley National Laboratories.

Sherman, M. (2010, June). Air Tightness: Experiences from US. Berkeley, CA, USA.

U.S. Census Bureau. (2011). American FactFinder. Retrieved October 17, 2013, from United States Census Bureau:

http://factfinder2.census.gov/faces/tableservices/jsf/pages/productview.xhtml?pid=AHS_2011_C 01AH\&prodType $=$ table

U.S. Census Bureau. (2013, June 27). State and Country Quick Facts. Retrieved October 17 , 2013, from US Department of Commerce: http:/quickfacts.census.gov/qfd/states/00000.html 
U.S. Department of Housing and Urban Development. (2012, March 7). PHA Contact Information. Retrieved November 12, 2012, from U.S. Department of Housing and Urban Development: http://www.hud.gov/offices/pih/pha/contacts/states/nc.cfm

U.S. DOE. (2008, August). Program Overview. Retrieved March 28, 2014, from WAPTAC: http://www.waptac.org/data/files/website_docs/briefing_book/wap_programoverview_final.pdf

U.S. DOE. (2013). Building Science-Based Climate Maps. Washington, D.C.: U.S. DOE.

US Census Bureau. (2011). American FactFinder. Retrieved October 17, 2013, from United States Census Bureau:

http://factfinder2.census.gov/faces/tableservices/jsf/pages/productview.xhtml?pid=AHS_2011_C 01AH\&prodType $=$ table

US Census Bureau. (2013, June 27). State and Country Quick Facts. Retrieved October 17, 2013, from US Department of Commerce: http://quickfacts.census.gov/qfd/states/00000.html

US EIA. (2013, March 13). Today in Energy. Retrieved October 17, 2013, from US Energy Information Administration:

http://www.eia.gov/todayinenergy/detail.cfm?id=10271\&src=\%E2\%80\%B9\%20Consumption $\%$ 20\%20\%20\%20\%20\%20Residential\%20Energy\%20Consumption\%20Survey\%20(RECS)-b1

US EPA. (2011, March). Energy Star Performance Ratings Methodology for Incorporating Source Energy Use. Retrieved November 20, 2013, from Energy Star:

http://www.energystar.gov/ia/business/evaluate_performance/site_source.pdf

VonSchrader, C. (2014, April 7). National Manager - Energy Star HVAC Verified Installation Program. (C. Liaukus, Interviewer) 


\section{Appendix A: BEopt Modeling}

The proposed packages, the BARA envelope package and the envelope + HVAC package, were modeled in BEopt, based on two homes in the study, the Delran home and the Mahwah home. When specific information about either home was not available (such as the existing water heater) values were kept consistent for the existing conditions and improved homes. The specific modeled packages and source energy savings percentage results are shown in Table 18.

Table 18. BEopt Model House Delran: Existing Conditions, HPwES Package, BARA Envelope Package, and BARA Envelope + HVAC Package

\begin{tabular}{|c|c|c|c|}
\hline \multicolumn{4}{|c|}{ Delran-1722-ft ${ }^{2}$ Home Circa 1990 Home } \\
\hline Existing Conditions & $\begin{array}{c}\text { Implemented } \\
\text { HPwES Package }\end{array}$ & $\begin{array}{c}\text { BARA Envelope } \\
\text { Package }\end{array}$ & $\begin{array}{l}\text { BARA Envelope } \\
+ \text { HVAC Package }\end{array}$ \\
\hline \multicolumn{4}{|l|}{ Envelope } \\
\hline \multicolumn{4}{|l|}{ Attic } \\
\hline R-19 & $\mathrm{R}-38$ & $\mathrm{R}-38$ & $\mathrm{R}-38$ \\
\hline \multicolumn{4}{|l|}{ Above Grade Walls } \\
\hline R-11 & $\mathrm{R}-11$ & $\mathrm{R}-11$ & R-11 \\
\hline \multicolumn{4}{|l|}{ Basement } \\
\hline No Insulation & Half wall R-5 & Whole wall R-5 & Whole wall R-5 \\
\hline \multicolumn{4}{|l|}{ Infiltration } \\
\hline 10ACH50 & $6 \mathrm{ACH} 50$ & $5 \mathrm{ACH} 50$ & $5 \mathrm{ACH} 50$ \\
\hline \multicolumn{4}{|l|}{ HVAC } \\
\hline $80 \%$ AFUE Furnace & $80 \%$ AFUE furnace & $80 \%$ AFUE Furnace & $\begin{array}{l}\text { 92.5\% AFUE } \\
\text { furnace } \\
\text { Duct sealing }\end{array}$ \\
\hline No AC & No AC & No AC & No AC \\
\hline \multicolumn{4}{|c|}{ BEopt \% Source Energy Savings } \\
\hline NA & $10 \%$ & $13 \%$ & $17 \%$ \\
\hline
\end{tabular}

Modeled results for the Delran home show The HPwES package achieving a 10\% source energy savings, $13 \%$ savings for the BARA envelope package and $17 \%$ savings for the envelope + HVAC package. The actual source energy savings for the implemented HPwES package at this home was $32 \%$ (Table 19).

Modeled results show The HPwES package for the Mahwah home achieving a $12 \%$ source energy savings, $14 \%$ savings for the BARA envelope package and $20 \%$ savings for the envelope + HVAC package. The actual source energy savings for the implemented HPwES package at this home was $30 \%$.

In both scenarios the modeled savings was considerably less than the actual source energy savings. ${ }^{10}$

\footnotetext{
${ }^{10}$ Some approximations of existing conditions had to be made in the BEopt models, for example the existing furnace in the Delran home was a 71 AFUE rather than 72 AFUE, and the existing infiltration for the home was actually 9 ACH50, improved to 6 ACH50 but was modeled as 10A CH50 improved to 6 ACH50.
} 
Comparison of the models with the actual savings results suggest that further research of actual source energy savings among HPwES homes, in New Jersey and in other climate zones, and the corresponding energy models (where utility bill data are not included) of those homes is desirable.

Table 19. BEopt Model of House Mahwah: Existing Conditions, HPwES Package, BARA Envelope Package, and BARA Envelope + HVAC Package

\begin{tabular}{|c|c|c|c|}
\hline \multicolumn{4}{|c|}{ Mahwah-1920-ft ${ }^{2}$ Home Circa 1970 Home } \\
\hline Existing Conditions & $\begin{array}{c}\text { Implemented } \\
\text { HPwES Package }\end{array}$ & $\begin{array}{c}\text { BARA } \\
\text { Envelope } \\
\text { Package }\end{array}$ & $\begin{array}{c}\text { BARA Envelope } \\
+ \text { HVAC } \\
\text { Package }\end{array}$ \\
\hline \multicolumn{4}{|l|}{ ENVELOPE } \\
\hline \multicolumn{4}{|l|}{ Attic } \\
\hline R-19 & $\mathrm{R}-38$ & $\mathrm{R}-38$ & $\mathrm{R}-38$ \\
\hline \multicolumn{4}{|l|}{ Above Grade Walls } \\
\hline R-11 & R-11 & R-11 & R-11 \\
\hline \multicolumn{4}{|l|}{ Basement } \\
\hline No Insulation & No insulation & Whole wall R-5 & Whole wall R-5 \\
\hline \multicolumn{4}{|l|}{ Infiltration } \\
\hline 15ACH50 & $10 \mathrm{ACH} 50$ & 8 ACH50 & 8 ACH50 \\
\hline \multicolumn{4}{|l|}{ HVAC } \\
\hline $80 \%$ AFUE Furnace & $\begin{array}{l}92.5 \% \text { AFUE } \\
\text { Furnace }\end{array}$ & $\begin{array}{l}\text { 80\% AFUE } \\
\text { Furnace }\end{array}$ & $\begin{array}{l}\text { 92.5\% AFUE } \\
\text { Furnace } \\
\text { Duct sealing }\end{array}$ \\
\hline No $\mathrm{AC}$ & SEER 18 & No AC & No AC \\
\hline \multicolumn{4}{|c|}{ BEopt \% Source Energy Savings } \\
\hline NA & $12 \%$ & $14 \%$ & $20 \%$ \\
\hline
\end{tabular}




\section{Appendix B: Case Study Content}

\section{Home Performance with ENERGY STAR Review-An Evaluation of Actual Energy Savings in New Jersey}

\section{Project Information}

BA has made significant strides in developing whole-house, proven performance packages to achieve high levels of energy savings - creating solid technical strategies for net-zero energyready homes - for new construction. However, whole-house, proven performance packages have been more difficult to develop for existing homes for a wide variety of reasons previously identified by researchers and practitioners (e.g., housing vintage, construction type). Data on actual savings achieved in homes with energy improvements are needed so that the most effective packages are developed and promoted by the BA program. Improving the energy efficiency of existing U.S. homes is critical for energy reduction in the residential sector. New construction accounts for a small fraction of the more than 130 million dwellings nationwide (U.S. Census Bureau, 2013).

HPwES is the largest national energy retrofit initiative (VonSchrader, 2014) and has been the mechanism for improving more than 372,000 homes since 2002. HPwES uses a "house as a system" approach and focuses on improvements to the building envelope and mechanical systems. HPwES contractors conduct energy audits on participating homes, prepare reports with recommended energy efficiency measures from an approved measures list, and install the selected measures.

New Jersey is one of 33 states with an active HPwES program. The New Jersey HPwES is part of New Jersey's Clean Energy Program, funded through the service benefits charge collected by the state's utilities and administered by the Board of Public Utilities. Nationally, the HPwES program has improved more than 200,000 homes since 2002. The New Jersey program has improved 12,033 homes since it began in 2006. HPwES projects have estimated savings of $10 \%$ $25 \%+$, depending on the implemented measures. These estimated savings are based on energy modeling with utility data input for pre-retrofit energy use.

In this BA research project, BARA worked with the New Jersey HPwES program, New Jersey Clean Energy Program, and eight utilities in New Jersey to evaluate the packages of measures implemented in 17 homes that have achieved an actual site energy savings in the range of $30 \%$. These savings are based on utility bill data, not only modeled savings.

This research verified that the New Jersey HPwES program is achieving savings in existing homes that meet or exceed BA's goal of $30 \%$. While savings ranging from $10 \%$ to $25 \%$ or more are estimated for the different HPwES tiers, no prior research had been done to verify actual savings by comparing pre- and post-retrofit utility bill data and documenting the measures implemented to achieve those savings. The research suggested that envelope packages could provide a lower cost option for HPwES contractors to recommend to consumers, creating broader market impact of HPwES.

The packages of measures used in the New Jersey HPwES program, both those with and without HVAC equipment replacement, can be included as part of a BA retrofit checklist for climate 
zones 4 and 5. Pairing the findings from this research with existing BA guidance documents, such as the Building America Best Practices Series, Energy Renovations, HVAC, (Pacific Northwest National Laboratory \& Oak Ridge National Laboratory, 2011) can help guide retrofit packages that tailor their approach toward more robust envelope improvements before mechanical equipment is replaced, resulting in relatively low-cost, high-impact energy improvement packages.

\section{Lessons Learned}

Some of the significant research questions and subsequent answers revealed by this research are as follows:

1. What was the average and individual difference between the projected post-retrofit energy use and the actual post-retrofit energy use?

Five of the 17 homes with utility data had lower actual savings than predicted, while 12 had higher savings. Savings exceeding predictions outweighed shortfalls, resulting in the average of predicted savings of $29.87 \%$, the average of actual site energy savings of $34.7 \%$, and the average of source energy savings of $38.03 \%$

2. What packages of measures were implemented in projects that had an actual energy use reduction of the $30 \%$ range?

Packages of measures varied, but the overall distinction is packages where heating and or cooling equipment was replaced or installed versus packages where this type of equipment was not installed. The packages with mechanical equipment had higher levels of savings that those without mechanical equipment (36\% versus $26 \%)$, but also had higher costs $(\$ 13,793$ versus $\$ 8,325)$. This suggests that both types of packages can meet the BA goals.

3. What prescriptive package, based on the results of question 2, might predictably deliver an energy savings reduction of $30 \%$ or more?

Example packages of both types are shown in Table 20 and Figure 20.

Table 20. Proposed Prescriptive Packages To Achieve 30\% Savings in Climate Zones 4 and 5

\begin{tabular}{|c|c|c|}
\hline Envelope Package & Measure & HVAC Package \\
\hline 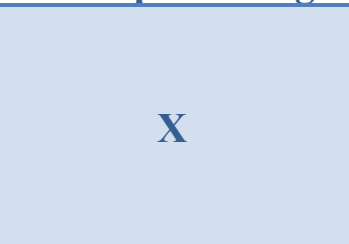 & $\begin{array}{l}\text { Air sealing to within } 200 \text { CFM50 of } \\
\text { BAS as attainable } \\
\text { or } \\
\text { Air sealing beyond the BAS and provide } \\
\text { mechanical ventilation }\end{array}$ & $X$ \\
\hline $\mathbf{X}$ & Attic hatch insulation to R-19 & $\mathrm{X}$ \\
\hline $\mathbf{X}$ & Attic floor insulation to R-38 & $\mathrm{X}$ \\
\hline $\mathbf{X}$ & Above grade wall insulation to $\mathrm{R}-13$ & \\
\hline \multirow[t]{4}{*}{$\mathbf{X}$} & Basement wall insulation to R-10 & \\
\hline & Replace heating equipment & $\mathrm{X}$ \\
\hline & Replace (or install) cooling equipment & $\mathrm{X}$ \\
\hline & Replace water heater & $\mathrm{X}$ \\
\hline
\end{tabular}




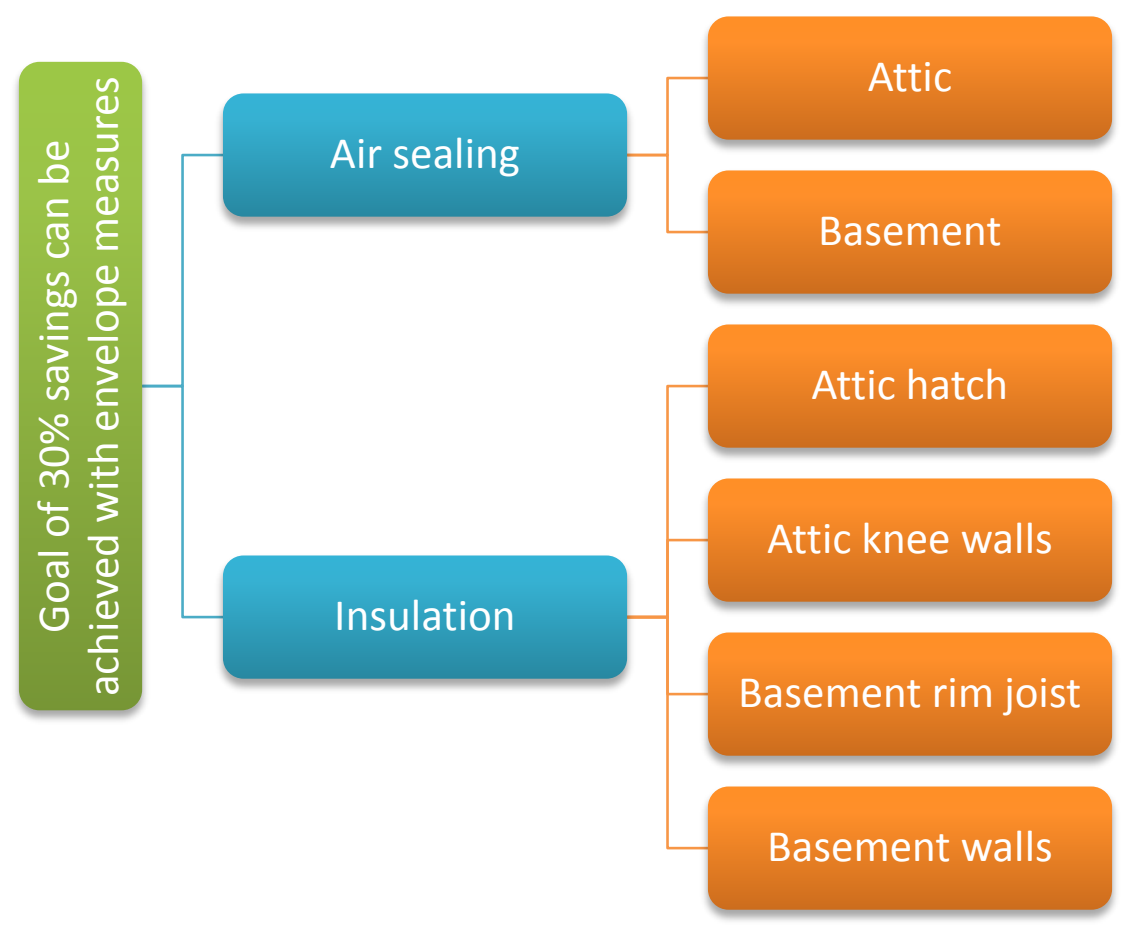

Figure 20. Envelope package areas of focus

The air sealing measure is shown with the criteria of tightening the home within 200 CFM50 of the BAS or beyond and providing mechanical ventilation. As noted earlier, among the 42 tier 3 level 2 New Jersey HPwES homes within this research, the average infiltration reduction was 715 CFM50 over their BAS. As such, more aggressive air sealing could make the envelope package even more robust (see Figure 21). 


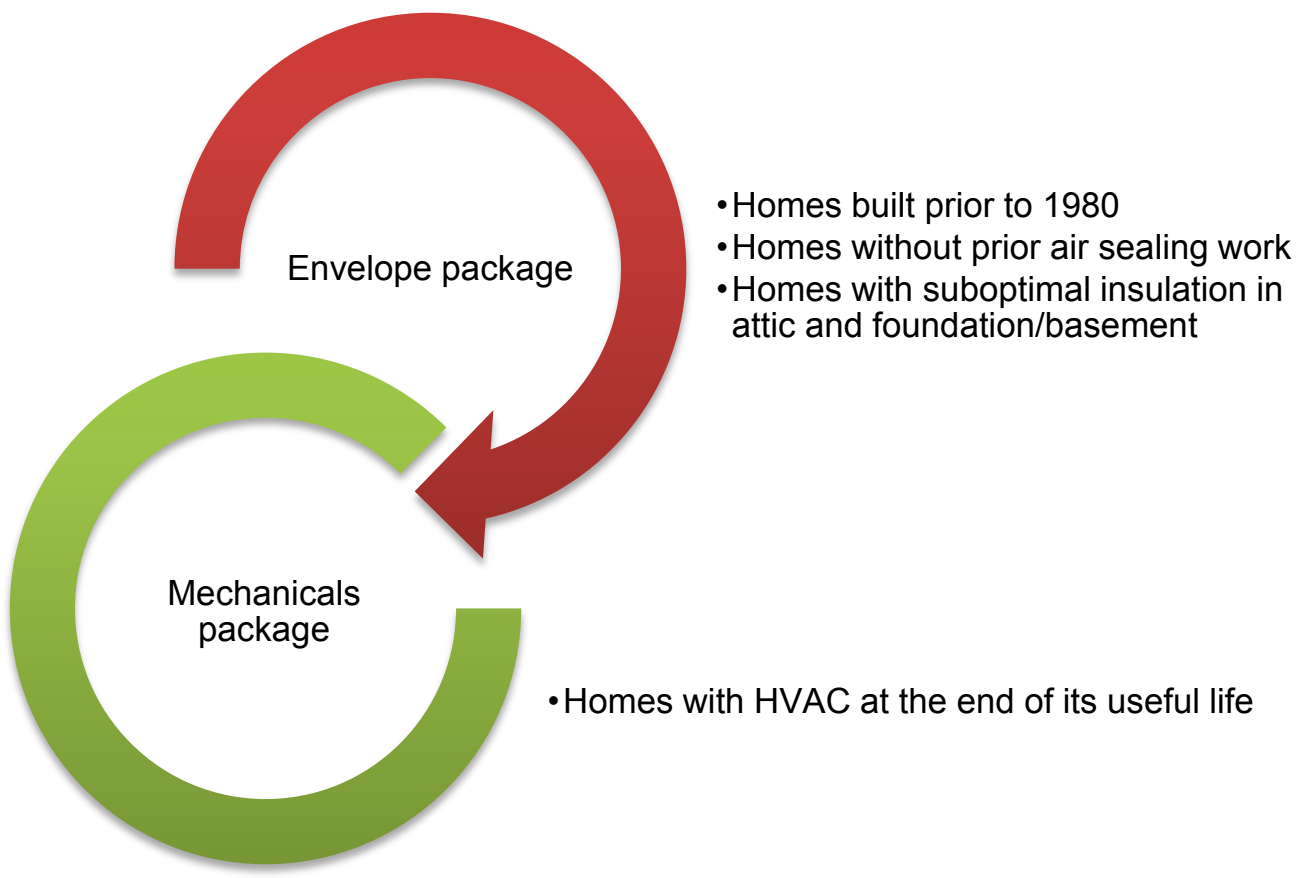

Figure 21. Existing conditions suited to envelope package and mechanicals package

4. What existing conditions, such as the existing infiltration rate, existing insulation levels, and/or efficiency of the mechanical system, would make a home a good candidate for the prescriptive package?

For the envelope package, homes built prior to 1980 that have not had previous energy work are good candidates. Homes of this age typically have suboptimal insulation levels (Roberts \& Stephenson, 2010). Older homes are also leakier than new homes, as shown by a study from the Florida Solar Energy Center. Granted, this is based on Florida homes, not New Jersey. Other studies have found that, generally, existing U.S. homes are very leaky and can be tightened $25 \%$ and still not be too tight (Sherman M. , 2010) (see Figure 22). 


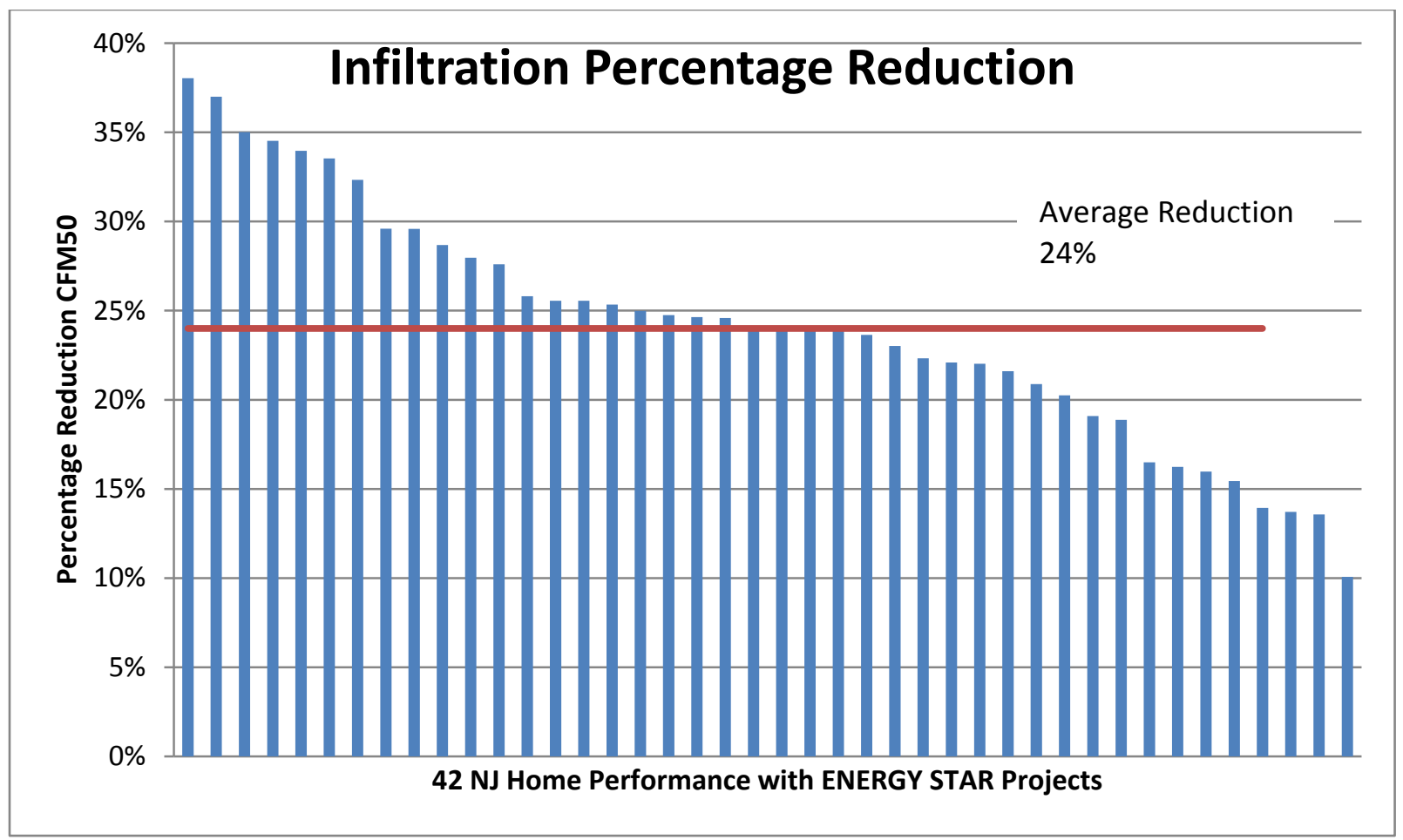

Figure 22. Infiltration percentage reduction

Any home that has heating equipment that needs to be replaced is a good candidate for the HVAC package. Most equipment lasts for about 20 years and homes from the 1990s and older could use the HVAC package. 
buildingamerica.gov 